\title{
IDENTIFICAÇÃO MOLECULAR DE ISOLADOS DO FITOPLASMA DO ENFEZAMENTO VERMELHO DO MILHO COLETADOS NO ESTADO DE SÃO PAULO
}

\section{LUCIANA BIANCHINI}

Dissertação apresentada à Escola Superior de Agricultura

"Luiz de Queiroz", Universidade de São Paulo, para obtenção do título de Mestre em Agronomia, Área de Concentração: Fitopatologia.

P I R A C I C A B A

Estado de São Paulo - Brasil

Dezembro - 2001 


\title{
IDENTIFICAÇÃO MOLECULAR DE ISOLADOS DO FITOPLASMA DO ENFEZAMENTO VERMELHO DO MILHO COLETADOS NO ESTADO DE SÃO PAULO
}

\section{LUCIANA BIANCHINI}

\author{
Engenheiro Agrônomo
}

Orientador: Prof. Dr. IVAN PAULO BEDENDO

\begin{abstract}
Dissertação apresentada à Escola Superior de Agricultura
"Luiz de Queiroz", Universidade de São Paulo, para obtenção do título de Mestre em Agronomia, Área de Concentração: Fitopatologia.
\end{abstract}

P I R A C I C A B A

Estado de São Paulo - Brasil

Dezembro - 2001 


\title{
Dados Internacionais de Catalogação na Publicação (CIP) DIVISÃO DE BIBLIOTECA E DOCUMENTAÇÃO - ESALQ/USP
}

\author{
Bianchini, Luciana \\ Identific a ção molecular de isolados do fitoplasma do enfeza mento \\ vermelho do milho coletadosno Estado de São Paulo / Luciana \\ Bianc hini. - - Piracic aba, 2001. \\ $45 \mathrm{p}$. \\ Dissertação (mestrado) - - Escola Superior de Agricultura Luiz de \\ Queiroz, 2001. \\ Bibliografia.
}

1. Doenças de plantas 2. Milho 3. Mycoplasma I. Título

CDD 633.15

"Permitida a cópia total ou parcial deste documento, desde que citada a fonte - $\mathrm{O}$ autor" 


\section{SUMÁRIO}

Página

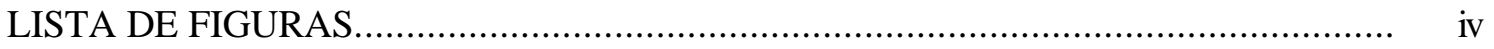

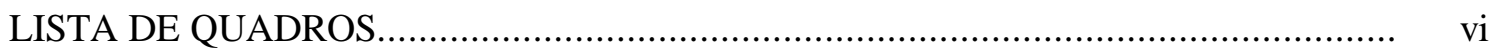

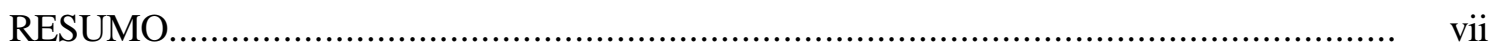

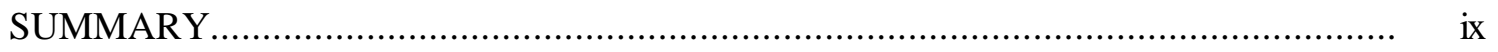

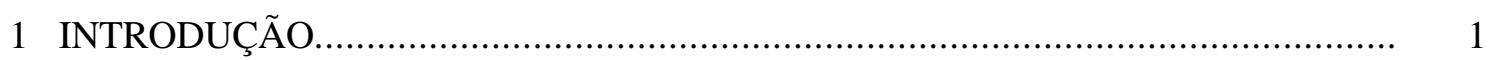

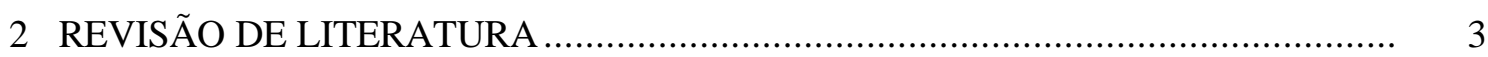

2.1 Importância e distribuição geográfica.................................................................... 3

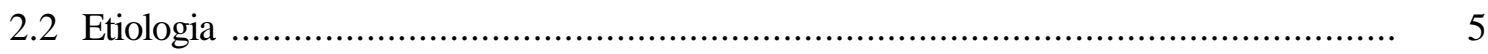

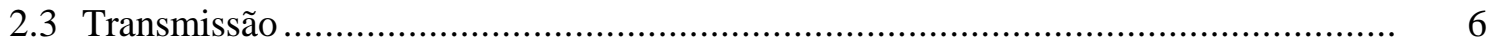

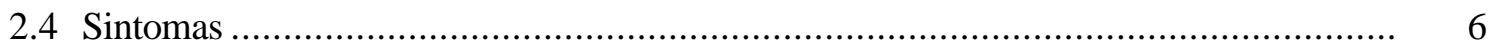

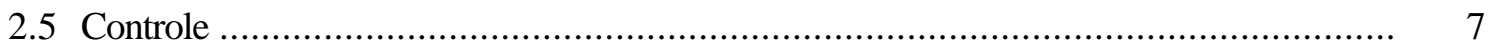

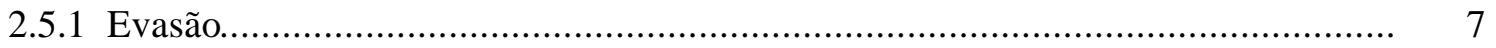

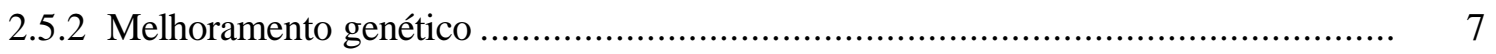

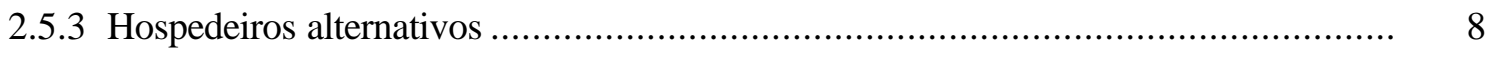

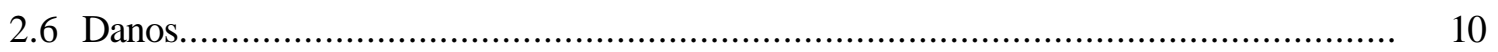

2.7 Detecção e Identificação do Fitoplasma ........................................................... 10

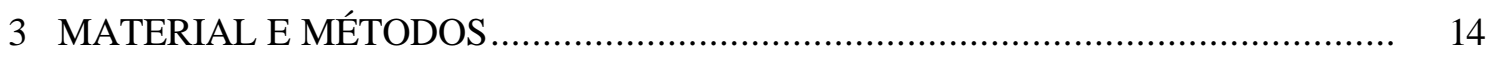

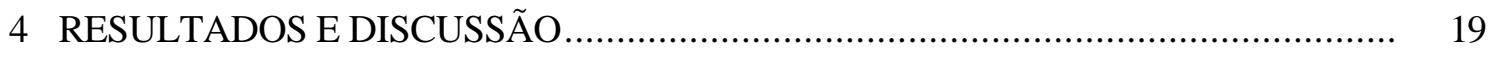

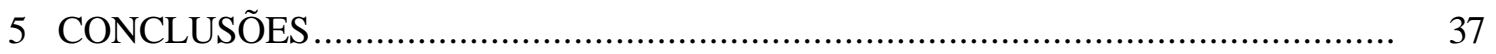

REFERÊNCIAS BIBLIOGRÁFICAS............................................................ 38 


\section{LISTA DE FIGURAS}

Página

1 Produtos da digestão enzimática com a endonuclease KpnI. Análise dos produtos de PCR duplo conduzido com os pares de oligonucleotídeos mF2/R1 e F2n/R2, utilizando DNA extraído de plantas de milho com sintomas de enfezamento, coletadas em quatro regiões do Estado de São Paulo: Guaíra (413, 400, 408, 409, 405,); Barretos (346, 343, 334, 349, 340); Piracicaba (81, 491, 509, 120, 502, 508); Santa Cruz das Palmeiras (294, 278, 303, 301, 306); e amostras positivas somente para o oligonucleotídeo universal nas 4 regiões: (Piracicaba: 79, 105; Santa Cruz das Palmeiras: 279, 302, 311; Barretos: 348; Guaíra: 404, 411). MM - padrão de peso molecular (de cima para baixo): 1353, 1078, 872, 603, 310, 281, 271, 234, 194, 118 pb.

2 Produtos da digestão enzimática com a endonuclease AluI. Análise dos produtos de PCR duplo conduzido com os pares de oligonucleotídeos mF2/R1 e F2n/R2, utilizando DNA extraído de plantas de milho com sintomas de enfezamento, coletadas em quatro regiões do Estado de São Paulo: Guaíra (413, 400, 408, 409, 405,); Barretos (346, 343, 334, 349, 340); Piracicaba (81, 491, 509, 120 , 502, 508); Santa Cruz das Palmeiras (294, 278, 303, 301, 306); e amostras positivas somente para o oligonucleotídeo universal nas 4 regiões: (Piracicaba: 79, 105; Santa Cruz das Palmeiras: 279, 302, 311; Barretos: 348; Guaíra: 404, 411). MM - padrão de peso molecular (de cima para baixo): 1353, 1078, 872, 603, 310, 281, 271, 234, 194, $118 \mathrm{pb}$

3 Produtos da digestão enzimática com a endonuclease MseI. Análise dos produtos de PCR duplo conduzido com os pares de oligonucleotídeos mF2/R1 e F2n/R2, utilizando DNA extraído de plantas de milho com sintomas de enfezamento, coletadas em quatro regiões do Estado de São Paulo: Guaíra (413, 
400, 408, 409, 405,); Barretos (346, 343, 334, 349, 340); Piracicaba (81, 491, 509, 120, 502, 508); Santa Cruz das Palmeiras (294, 278, 303, 301, 306); e amostras positivas somente para o oligonucleotídeo universal nas 4 regiões: (Piracicaba: 79, 105; Santa Cruz das Palmeiras: 279, 302, 311; Barretos: 348; Guaíra: 404, 411). MM - padrão de peso molecular (de cima para baixo): 1353, 1078, 872, 603, 310, 281, 271, 234, 194, 118 pb. 34

4 Produtos da digestão enzimática com a endonuclease RsaI. Análise dos produtos de PCR duplo conduzido com os pares de oligonucleotídeos mF2/R1 e F2n/R2, utilizando DNA extraído de plantas de milho com sintomas de enfezamento, coletadas em quatro regiões do Estado de São Paulo: Guaíra (413, 400, 408, 409, 405,); Barretos (346, 343, 334, 349, 340); Piracicaba (81, 491, 509, 120, 502, 508); Santa Cruz das Palmeiras (294, 278, 303, 301, 306); e amostras positivas somente para o oligonucleotídeo universal nas 4 regiões: (Piracicaba: 79, 105; Santa Cruz das Palmeiras: 279, 302, 311; Barretos: 348; Guaíra: 404, 411). MM - padrão de peso molecular (de cima para baixo): 1353, 1078, 872, 603, 310, 281, 271, 234, 194, $118 \mathrm{pb}$

5 Produtos da digestão enzimática com a endonuclease HhaI. Análise dos produtos de PCR duplo conduzido com os pares de oligonucleotídeos mF2/R1 e F2n/R2, utilizando DNA extraído de plantas de milho com sintomas de enfezamento, coletadas em quatro regiões do Estado de São Paulo: Guaíra (413, 400, 408, 409, 405,); Barretos (346, 343, 334, 349, 340); Piracicaba (81, 491, 509, 120, 502, 508); Santa Cruz das Palmeiras (294, 278, 303, 301, 306); e amostras positivas somente para o oligonucleotídeo universal nas 4 (Piracicaba: 79, 105; Santa Cruz das Palmeiras: 279, 302, 311; Barretos: 348; Guaíra: 404, 411). MM - padrão de peso molecular (de cima para baixo): 1353, $1078,872,603,310,281,271,234,194,118 \mathrm{pb}$ 


\section{LISTA DE QUADROS}

Página

1 Amostras obtidas de plantas de milho coletadas na região de Guaíra, apresentando sintomas de enfezamento vermelho, submetidas a PCR com diferentes oligonucleotídeos para detecção ou identificação do fitoplasma

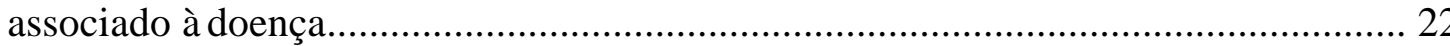

2 Amostras obtidas de plantas de milho coletadas na região de Piracicaba, apresentando sintomas de enfezamento vermelho, submetidas a PCR com diferentes oligonucleotídeos para detecção ou identificação do fitoplasma associado à doença

3 Amostras obtidas de plantas de milho coletadas na região de Barretos, apresentando sintomas de enfezamento vermelho, submetidas a PCR com diferentes oligonucleotídeos para detecção ou identificação do fitoplasma

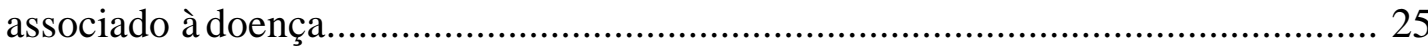

4 Amostras obtidas de plantas de milho coletadas na região de Santa Cruz das Palmeiras, apresentando sintomas de enfezamento vermelho, submetidas a PCR com diferentes oligonucleotídeos para detecção ou identificação do fitoplasma associado à doença

5 Isolados provenientes da região de Guaíra selecionados para análise de RFLP e sua detecção com os diferentes oligonucleotídeos............................................... 28

6 Isolados provenientes da região de Piracicaba selecionados para análise de RFLP e sua detecção com os diferentes oligonucleotídeos

7 Isolados provenientes da região de Barretos selecionados para análise de RFLP e sua detecção com os diferentes oligonucleotídeos.

8 Isolados provenientes da região de Santa Cruz das Palmeiras selecionados para análise de RFLP e sua detecção com os diferentes oligonucleotídeos. 


\section{IDENTIFICAÇÃO MOLECULAR DE ISOLADOS DO FITOPLASMA DO ENFEZAMENTO VERMELHO DO MILHO COLETADOS NO ESTADO DE SÃO PAULO}

Autora: LUCIANA BIANCHINI

Orientador: Prof. DR. IVAN PAULO BEDENDO

\section{RESUMO}

A partir de meados da década de 80, com a expansão da cultura do milho para além das épocas tradicionais de cultivo, quer pela prática da safrinha ou por plantios irrigados, vem ocorrendo um aumento na incidência de doenças a secundária. Dentro deste contexto, o enfezamento vermelho do milho, relatado no país primeiramente em 1970, vem ocorrendo de forma freqüente, apresentando altos índices de ocorrência, muitas vezes com comprometimento total da produção. As plantas infectadas apresentam uma sintomatologia complexa facilmente confundida com viroses. O sintoma mais característico é o avermelhamento foliar. Além do avermelhamento as plantas apresentam redução na altura, perfilhamento basal e axilar, espigas extranumerárias e colmos afinados. Essa doença é causada por um procarioto não cultivável em meio de cultura, habitante exclusivo do floema, denominado fitoplasma, veiculado de forma persistente e propagativa pela cigarrinha Dalbulus maidis. Devido às características do patógeno, a única forma de controle promissora é a utilização de variedades tolerantes/resistentes. Para eficiência na obtenção destas 
variedades é necessário um diagnóstico correto e conhecimento sobre a variabilidade metodologia mais eficiente tanto para diagnose correta como para investigar essa variabilidade tem sido o PCR. O PCR, utilizando oligonucleotídeos baseados no gene 16SrDNA seguido da análise de RFLP, proporciona uma identificação lmente a classificação de fitoplasmas é fundamentada no perfil molecular obtido por análise de RFLP de fragmentos do gene 16SrDNA amplificados. Com base nestas considerações, o trabalho teve como objetivo caracterizar molecularmente isolados do fitoplasma associado ao enfezamento vermelho do milho, coletados em quatro regiões produtoras de milho do estado de São Paulo. A sintomatologia para cada amostra de milho foi anotada. Foram usados dois pares de oligonucleotídeos universais para fitoplasmas em duplo PCR, um par de oligonucleotídeo especificamente desenvolvido para detecção do fitoplasma do enfezamento vermelho do milho, além de oligonucleotídeos para detecção de fitoplasmas pertencentes a grupos específicos. Após amplificação e eletroforese, 29 isolados foram selecionados para a identificação através de RFLP. Fragmentos de DNA foram submetidos à digestão com diferentes enzimas de restrição com o objetivo de identificar/classificar o fitoplasma. Os padrões de bandas obtidos após a eletroforese em gel de poliacrilamida foram comparados com os padrões atuais para classificação dos fitoplasmas. Todos os isolados analisados apresentaram idênticos padrões de bandas, para cada enzima de restrição, considerada individualmente. Não houve diferenciação de acordo com a região geográfica de coleta ou de acordo com intensidade de sintomas apresentados. Todos os isolados foram identificados como pertencentes ao grupo I e subgrupo B da classificação molecular atualmente adotada para estes microorganismos. 


\title{
MOLECULAR IDENTIFICATION OF MAIZE BUSHY STUNT PHYTOPLASM STRAINS COLLECTED IN SÃO PAULO STATE
}

\author{
Author: LUCIANA BIANCHINI \\ Adviser: Prof. DR. IVAN PAULO BEDENDO
}

\section{SUMMARY}

Since the middle $80 \mathrm{~s}$, an increase in year round cropping of maize resulted in a spread of secondary diseases in the crop's major production areas. In this context, maize busy stunt, firstly appointed in Brazil in 1970, is occurring more frequently, often with total damage of production. Infected plants show a complex symptomatology, easily confounded with virus-caused diseases. The most characteristic symptom is leaf reddening. Besides the reddening diseased plants show stunting, often developing tillering. This disease is caused by a phytoplasma, a wall-less prokaryote, uncultivable, phloem inhabitant. This pathogen is transmitted by the leafhopper Dalbulus maidis, a in persistent and propagative manner. Due to the pathogen's characteristics, the best control measure is the use of tolerant/resistant plants. For efficiency in breeding, accurate procedures of detection and an investigation of the pathogen's genetic variability are necessary. The more accurate manner is using PCR. PCR, using 16SrDNA based primers pairs and followed by RFLP analysis, offers a safe identification of the pathogen. Today the phytoplasma classification is based in molecular patterns obtained by RFLP analysis of amplified 16SrDNA gene fragments. 
This work's objective was the molecular characterization of maize bushy stunt phytoplasma strains collected in four corn production areas in São Paulo state, Brazil. The simptomatology to every maize sample was saved. Two primer pairs in nested PCR and a specific primer pair developed to MBS detection were used, besides group specific phytoplasma primers pairs. After amplification and electrophoresis, 29 samples were selected. These selected samples were digested with different restriction enzymes to identify/classify the phytoplasma. The fragment's sizes obtained by electrophoresis through $4,5 \%$ polyacrilamide gel were compared with the reference's classification patterns. All analyzed samples showed identical fragment-size patterns, for each restriction enzyme considered individually. There was no difference between these samples according to geographic collect region or according to symptoms. All strains were identified as belonging to group I and subgroup B of molecular classification. 


\section{INTRODUÇÃO}

O enfezamento vermelho do milho, doença causada por um fitoplasma habitante de floema, vem ocorrendo com alta incidência tanto nas culturas instaladas em épocas normais de cultivo, como nas épocas não tradicionais (safrinha). Observações de

campo têm mostrado índices de incidência até $100 \%$, comprometendo totalmente a produção da cultura. Avaliações de perdas tem demonstrado a importância do enfezamento, o qual chega a reduzir a produção em até $0,8 \%$ para cada $1 \%$ de incidência da doença. A alta frequiência da doença tem sido atribuída à permanência da cultura no campo durante quase o ano todo, devido tanto aos plantios irrigados como à ex área de cultivo de milho safrinha no Brasil.

Para o adequado manejo e controle dessa doença numa cultura de grande expressão como o milho, há necessidade de se conhecer melhor a variabilidade genética do patógeno, a qual tem grande importância na epidemiologia da doença e grande utilidade em programas de melhoramento que buscam a criação de variedades/híbridos resistentes. Como a doença é causada por um organismo não cultivável em meio de cultura, os métodos tradicionais para a identificação baseados em caracteres morfológicos e fisiológicos não se aplicam a este tipo de patógeno. A identificação para estes microorganismos tem sido feita através de metodologias moleculares como as técnicas de PCR (Polymerase Chain Reaction) e RFLP (Restriction Fragment Length Polymorphism). Estas técnicas têm se mostrado altamente sensíveis tanto para a detecção como para a identificação de fitoplasmas que ocorrem em plantas e insetos.

O fitoplasma associado ao enfezamento vermelho do milho tem sido consistentemente identificado como pertencente ao grupo I, subgrupo B, de acordo com a classificação atualmente adotada para fitoplasmas. No entanto, algumas evidências 
levam a suspeita de ocorrência de fitoplasma associados ao enfezamento vermelho, cuja identidade é diversa do grupo I-B.

O objetivo do presente trabalho foi promover a identificação de isolados do fitoplasma associado ao enfezamento vermelho do milho, coletados em algumas áreas de plantio comercial, localizadas no Estado de São Paulo. 


\section{REVISÃO DE LITERATURA}

\subsection{Importância e distribuição geográfica}

Em 1955, dois tipos de enfezamento do milho foram descritos no território mexicano (Maramorosch, 1955). O primeiro foi designado por enfezamento tipo Rio Grande, originalmente reportado no Texas, na década de quarenta (Kunkel, 1946). O segundo foi denominado enfezamento tipo Mesa Central, por ocorrer em regiões do planalto central do México.

No início das investigações, devido às características sintomáticas da doença e à forma de transmissão, considerou-se que as doenças eram de etiologia viral e que o vírus possuía dois variantes, cada um associado a um dos tipos de enfezamento (Maramorosch, 1955). Pesquisas conduzidas alguns anos mais tarde revelaram que um espiroplasma era o agente do enfezamento tipo Rio Grande e que um micoplasma estava associado ao enfezamento tipo Mesa Central (Granados, 1969; Chen \& Granados, 1970; Davis et al., 1972). Posteriormente, a doença causada pelo espiroplasma recebeu o nome de "Com Stunt" e aquela associada ao micoplasma foi denominada de "Maize Bushy Stunt (Davis, 1981). Atualmente os micoplasmas associados a doenças de plantas são referidos como fitoplasmas (Sears \& Kirkpatrick, 1994), porém os espiroplasmas mantém a denominação original (Davis et a1., 1972).

No Brasil, ambos os tipos de enfezamento foram constatados no início da década de 70, em milharais do Estado de São Paulo (Costa et al., 1971). Pela comparação de sintomas, o "Com Stunt" foi chamado de enfezamento pálido, enquanto o "Maize Bushy Stunt" foi denominado de enfezamento vermelho. As doenças foram registradas

como tendo pouca importância para culturas instaladas em época normal de plantio, porém a incidência era mais freqüente no inverno, provavelmente devido à 
escassez de outras plantas normalmente hospedeiras da cigarrinha vetor Dalbulus maidis (Kitajima \& Costa, 1970).

Apesar de constatada no início da década de setenta, as doenças passaram a se manifestar de forma epidêmica somente em meados da década de oitenta, devido ao plantio tardio do milho, chamado de milho safrinha, prática que se tornou comum em várias áreas da região Sul, Sudeste e Centro-Oeste (Bedendo, 1997; Oliveira et al., 1997). O milho de safrinha tem sido plantado de janeiro a março, aproveitando os recursos ociosos da entressafra (Garcia, 1997). Com o passar do tempo também o milho plantado em época normal passou a sofrer grandes perdas devido aos enfezamentos, chegando a ser fator limitante de produção em algumas áreas do país (Oliveira et al., 1998).

A doença ocorre em praticamente toda a América Latina e no sul dos EUA provocando danos variáveis (Rahman, 1998; Hruska et al., 1996; Tsai \& Falk, 1998). Na Nicarágua, do início da década de 80 até o início dos anos 90, a incidência de enfezamento aumentou de níveis insignificantes para níveis ala recuando posteriormente a níveis insignificantes. Como não houve mudanças nas variedades de milho plantadas, nem na população de insetos vetores, a provável explicação foi o aumento abrupto na produção de milho irrigado durante a esta quando o milho não era tradicionalmente plantado (Hruska et al., 1996). Assim o milho irrigado na Nicarágua, do mesmo modo que o milho safrinha no Brasil, forneceu uma ponte temporal para os patógenos que foram transmitidos para os plantios da es chuvosa, causando sérias epidemias para a cultura.

O enfezamento pálido e o vermelho podem ocorrer de forma isolada ou conjunta, pois os agentes causais são transmitidos pelo mesmo inseto vetor (Nault, 1980). Ambos têm assumido grande importância nas regiões de clima quente e úmido, porém o enfezamento vermelho vem se mostrando mais destrutivo que o enfezamento pálido, ocorrendo com maior frequiência, provocando o aparecimento de sintomas mais precocemente e causando maiores danos (Oliveira et al., 1998; Massola et al., 1997). 


\subsection{Etiologia}

Os fitoplasmas estão associados às doenças conhecidas por amarelos, as quais ocorrem em uma ampla variedade de culturas economicamente importantes (McCoy et al, 1989). Na natureza são veiculados por diferentes espécies de homópteros, geralmente de maneira persistente e são transmitidos para diferentes plantas hospedeiras ( Gundersen et al, 1996; Gundersen \& Lee, 1996).

Apesar das inúmeras tentativas de cultura axênica, incluindo meios similares àqueles utilizados para micoplasmas patogênicos ao homem e animais, a cultura de fitoplasmas ainda não é possível. Devido a esse fato, a prova de patogenicidade permanece incompleta apesar das fortes evidências da patogenicidade que têm sido apresentadas por inúmeros pesquisadores (Seemuller et al., 1998),

Inicialmente os fitoplasmas foram chamados de micoplasmas "mycoplasmalike organisms" (MLOs) -devido à semelhança morfológica e ultraestrutural, revelada ao microscópio eletrônico, com os micoplasmas tipicamente encontrados em animais e humanos, bem como com os micoplasmas saprófitos. No entanto, o genoma dos chamados fitoplasmas não é tão similar ao genoma desses verdadeiros micoplasmas. Esses organismos são procariotos unicelulares, onde o material genético não é envolto por uma membrana, não apresentando, portanto, um núcleo organizado. O citoplasma é circundado apenas pela membrana celular e a ausência da parede celular lhe confere o pleomorfismo. São sensíveis à tetraciclina. Quando plantas doentes são imersas em solução de tetraciclina ocorre remissão temporária de sintomas, bem como a eliminação temporária dos fitoplasmas presentes nos tecidos vegetais (Davis, 1981).

Atualmente os fitoplasmas estão inseridos na classe Mollicutes e estudos de homologia de DNA em genes altamente conservados, que codificam RNA, DNA e proteínas ribossômicos, têm mostrado que os fitoplasmas compreendem um grupo distinto de todos os outros procariotos (Harrison et al, 1996).

Atualmente são classificados em grupos com base em análises de RFLP de fragmentos do gene 16SrDNA amplificados (Lee et al, 1998). Vários grupos de fitoplasmas têm sido diferenciados com base na variação de sequências de nucleotídeos 
do gene $16 \mathrm{~S}$ ribossômico. A classificação é baseada primariamente no tamanho do genoma e na filogenia deduzida da seqüência de nucleotídeos do gene 16SrRNA (Harrison et al, 1996).

Através das técnicas moleculares de PCR e RFLP, o fitoplasma associado ao enfezamento vermelho que ocorre na América do Norte foi classificado como pertencente ao grupo I, subgrupo I-B (Gundersen et al., 1996). Trabalhos posteriores conduzidos por Lee et al. (1998) confirmaram a classificação deste fitoplasma como membro do grupo I-B. Alguns isolados obtidos de variedades e híbridos cultivados no Brasil também foram identificados como componentes do grupo I-B (Bedendo et al., 1997, Bedendo et al, 2000), embora houvesse sido relatado que possivelmente isolados pertencentes a outros grupos estivessem ocorrendo (Barros, 1997).

\subsection{Transmissão}

A cigarrinha do milho Dalbulus maidis é o principal vetor do fitoplasma associado ao enfezamento vermelho em áreas tropicais e subtropicais, sendo abundante desde o sul dos EUA até a Argentina (Tsai \& Falk, 1998). Esse fitoplasma é também transmitido experimentalmente por D. elimatus, de modo persistente (Oliveira et al., 1997; Tsai \& Falk, 1998). Outras espécies como Dalbulus guevarai; D. gelbus, Exitianus exitiosus, Stirelus bicolor; Euselidius variegatus, (Granados, 1969; Whitcomb, 1989; Nault, 1980), Baudulus tripsaci, Craminiella nigrifons, e C. sonorus (Nault, 1980, Tsai \& Falk,1998) também se mostraram aptas a transmitir o fitoplasma. Nos EUA a taxa de transmissão por D. maidis varia de 43,9 a 88,0\% e quando transmitido por D. elimatus e C. nigrifons é 58,8 e 8,2\% respectivamente (Tsai \& Falk, 1998). No Brasil predomina a cigarrinha D. maidis como vetor e dentro do gênero Dalbulus é a única espécie presente no país, com picos populacionais registrados em março e abril (Oliveira et al., 1997).

\subsection{Sintomas}

A sintomatologia apresentada por plantas infectadas pelo fitoplasma é complexa, sendo facilmente confundida com viroses ou, às vezes, com o enfezamento 
pálido. Além disso, muitas vezes as plantas infectadas mostram-se assintomáticas (Maramorosch, 1988; Tsai \& Falk, 1998).

Embora a maioria dos fitoplasmas cause amarelecimento em plantas, o avermelhamento foliar, tem sido o sintoma mais característico associado à presença do fitoplasma no milho (Bedendo, 1999; Tsai \& Falk, 1998). Plantas inoculadas com o fitoplasma, inicialmente desenvolvem clorose marginal nas folhas, seguida de avermelhamento (Tsai \& Falk, 1998; Bedendo, 1999; Massola et al., 1999).

O quadro sintomatológico comumente envolve, além do avermelhamento foliar, redução na altura de plantas, proliferação de espigas mal formadas e afinamento de colmos (Toffanelli \& Bedendo, 2001). Eventualmente, em função do híbrido ou variedade, pode ser observada a presença de perfilhos na base da planta e nas axilas das folhas, além de leve enrolamento das folhas (Toffanelli, 2001).

\subsection{Controle}

\subsubsection{Evasão}

Patógenos transmitidos por insetos são mais difíceis de serem controlados. Uma medida de controle seria evitar plantios de milho tardios (safrinha). Essa medida não é economicamente adequada, pois a safrinha é uma prática amplamente adotada nas principais regiões produtoras do país, onde se encontra uma franca expansão da cultura. Ressalta-se que o milho de safrinha é responsável por $16 \%$ da produção total de milho

\subsubsection{Melhoramento genético}

A medida mais recomendada e promissora de controle é o uso de plantas tolerantes ou resistentes (Ullstrup, 1978; Shurtleff, 1986, Tsai \& Falk, 1998). Especialmente para fitoplasmas, o melhoramento para resistência se constitui numa forma de controle altamente desejável em função do custo-benefício e da probabilidade de sucesso (Maramorosch, 1988). Tentativas de encontrar resistência a doenças causadas por fitoplasmas tem sido feitas por longo tempo antes mesmo que os fitoplasmas tivessem sido reconhecidos como agentes causais de doenças (Maramorosch, 1988). A 
utilização de melhoramento visando resistência ao enfezamento vermelho se justifica devido à existência de variação genética dentro do milho em relação a ambas formas de enfezamento (Maramorosch, 1988; Borges, 1997; Dudienas et al., 1997).

Existem relatos de material de milho tolerante (Tsai \& Falk, 1998) e resistente (Massola, 1998), mas se desconhece a variabilidade do fitoplasma. Para fitoplasmas de modo geral, tem sido constatado que certos variantes são bastante virulentos, causando severas perdas, enquanto outros são brandos e os sintomas induzidos são dificilmente reconhecidos (Maramorosch, 1988). Essa variabilidade causa problemas para o melhoramento genético, pois a variedade resistente a um variante pode ser suscetível a outro. Tem sido relatado também que plantas infectadas com um variante brando de fitoplasma podem não desenvolver sintomas severos quando subseqüentemente inoculadas com um variante severo do mesmo fitoplasma (Maramorosch, 1988). Assim interpretações errôneas num programa de melhoramento podem levar ao desenvolvimento de variedades falsamente resistentes. No caso específico do milho, apesar de se conhecer a variabilidade genética do milho em relação aos dois tipos de enfezamento, as informações sobre a variabilidade de fitoplasma associado ao enfezamento vermelho são muitos escassas.

\subsubsection{Hospedeiros alternativos}

Em alguns casos é possível reduzir a disseminação de uma doença de fitoplasma pela remoção de hospedeiros alternativos. Geralmente é difícil ou mesmo

o nos casos em que os hospedeiros são perenes ou florestais (Maramorosch, 1988).

McCoy et al. (1989) citam como hospedeiros para o fitoplasma do enfezamento vermelho apenas as espécies Zea mays (milho) e Zea mays mexicana (teosinto). No entanto, nessa época, as técnicas de detecção eram pouco sensíveis. Whitcomb (1989) afirmou que parecia faltar um hospedeiro perene suscetível para o fitoplasma do milho nos EUA, para explicar a sobrevivência do patógeno no inverno, fora da estação de cultivo, apesar desse fitoplasma ter sido encontrado infectando naturalmente Catharanthus roseus. 
Praticamente não há informações sobre hospedeiros alternativos para o fitoplasma do milho, porém, com base em informações sobre a existência de hospedeiros alternativos para outros fitoplasmas, pode-se levantar a hipótese da existência de hospedeiros alternativos para esse fitoplasma. Mesmo para outros fitoplasmas pertencentes ao grupo I, só recentemente plantas daninhas foram testadas visando à identificação molecular de fitoplasmas abrigados por elas. A ocorrência de infecções assintomáticas nesses tipos de plantas também é comum. Como um dos exemplos podese citar que, no norte da Itália, em plantações de Olmo com declínio foram encontradas plantas daninhas assintomáticas infectadas com fitoplasmas pertencentes ao $16 \mathrm{SrI}$ (subgrupo B ou C) (Seemüller et al., 1998).

Algumas evidências suportam esta hipótese de hospedeiros alternativos. Whitcomb (1989) observou que o espiroplasma do milho (S. kunkelli) poderia infectar plantas de rabanete e, inclusive, ser transmitido para plantas de Lolium sp. Um fitoplasma não identificado, abundante em floema de plantas com virescência, pôde ser transmitido, por cigarrinhas, da beterraba para mostarda, nabiça e Catharanthus roseus (Calavan \& Bové, 1989). Este fitoplasma também foi transmitido por uma espécie de cigarrinha a espécies de plantas pertencentes às famílias Apocynaceae, Asteraceae, Brassicaceae, Ranunculaceae e Tropaeolaceae $\left(\right.$ Sullivan $^{1}$ et al. citados por Calavan $\&$ Bové, 1989).

A ocorrência de fitoplasma do grupo I, particularmente o subgrupo B, em uma monocotiledônea, nesse caso o milho, é única, sendo que todos os demais fitoplasmas pertencentes a esse grupo infectam dicotiledôneas. Isso é uma evidência da adaptabilidade desse fitoplasma (Bertaccini, 2000).

1 SUllivan, D. A.; OLDFIELD, G. N.; GUMPF, D. J. A preliminary biological characterization of the beet leafhopper transmitted virescence agent (BTLVA) from California. Phytopathology, v.75, n.11, p.1380, 1985. 


\subsection{Danos}

Em um estudo sobre as perdas na produção devido ao complexo do enfezamento do milho, Scott et al. (1977) verificaram que a produção das plantas doentes foi menor do que $50 \%$ da produção de plantas sadias. O número de espigas e grãos por planta foi muito reduzido, assim como o peso dos grãos. Plantas doentes que exibiam sintomas logo aos 52 dias após o plantio não produziam nenhum grão. Plantas mostrando os primeiros sintomas mais tarde, aos 107 dias após o plantio, mostraram uma produção normal. Entre esses dois extremos, a produção das plantas doentes foi reduzida em média 1,82\% ao dia. Num estudo mais recente, Massola (1998) obteve correlações positivas entre danos e incidência do complexo do enfezamento. Para cada $1 \%$ de aumento da incidência, verificou-se um dano de $0,8 \%$ na produção para os híbridos testados. Essa mesma variação na incidência provocou reduções no peso de 1000 grãos de $0,8 \%$ para um dos híbridos e 0,4\% para o outro. Entre os dois molicutes envolvidos, o fitoplasma mostrou-se mais agressivo que o espiroplasma, induzindo o aparecimento de sintomas mais precocemente e causando maiores danos.

\subsection{Detecção e Identificação do Fitoplasma}

O enfezamento vermelho pode ser caracterizado com base nos sintomas. Embora exista um quadro sintomatológico para a doença, a diagnose pode ser prejudicada pela ocorrência de infecções mistas, com viroses do milho ou mesmo com o enfezamento pálido (Harrison et al., 1996, Bedendo, 1997). A dificuldade na diagnose é agravada pelas variações nos sintomas devido ao genótipo do hospedeiro, variante do patógeno e condições ambientais (Nault, 1980; Harrison et a1., 1996).

A primeira detecção precisa do fitoplasma em plantas de milho doentes e vetores infectivos foi feita em 1968, através de microscópio eletrônico de transmissão (Granados, 1969). A diagnose com base nos sintomas passou então a ser confirmada pela detecção do fitoplasma no floema, usando microscópio de transmissão eletrônica (Harrison et al, 1996).

Além da microscopia eletrônica, outros métodos foram desenvolvidos e têm sido utilizados na detecção de fitoplasmas, como a coloração específica do DNA com 
DAPI (4',6-diamidino-2-fenilindol.2HCl) e sua detecção em microscópio de epifluorescência, métodos sorológicos e moleculares (hibridização e PCR) (Harrison et al., 1996; Sinclair et al., 1996).

A microscopia eletrônica e o DAPI são métodos não específicos e não proporcionam informação sobre a identidade do fitoplasma. Os métodos sorológicos envolvendo anticorpos monoclonais e policlonais melhoraram a deteç̧ão de vários molicutes fitopatogênicos, inclusive do fitoplasma do milho. No entanto, uma detecção mais específica e sensível de numerosos fitoplasmas tem sido alcançada pela hibridização de DNA utilizando sondas de fragmentos DNA do fitoplasma clonados (Harrison et al., 1996; Gundersen et al., 1996).

Atualmente, métodos de detecção muito mais sensíveis estão disponíveis. O PCR, usando seqüências de oligonucleotídeos ("primers") derivados de seqüências do gene RNA ribossômico (rRNA) dos molicutes, ou de fragmentos anônimos de DNA clonados, tem aumentado a sensibilidade de detecção, quando comparado com os demais métodos de deteç̧ão. O PCR tem se tornado dominante devido a sua alta sensibilidade, oferecendo muitas vantagens e facilitando a detecção e a identificação de fitoplasmas, já que estes podem ocorrer em baixas quantidades nas plantas e freqüentemente ocorrem de forma errática. (Gundersen et al., 1996; Harrison et al., 1996).

Em experimento realizado por Harrison et al., (1996) a presença do fitoplasma associado ao enfezamento vermelho em amostras de folhas e hastes obtidas de plantas pré-sintomáticas foi prontamente demonstrada pelo PCR específico para esse fitoplasma. Comparativamente, a deteç̧ão foi mal sucedida quando essas amostras foram testadas por hibridização usando sondas de DNA cromossômico desse fitoplasma. Uma inabilidade semelhante para deteç̧ão do fitoplasma associado ao enfezamento vermelho do milho em nervuras de plantas de milho pré-sintomáticas já tinha sido anteriormente reportada, apesar de a detecção ter sido bem sucedida quando DNA extracromossomal (plasmídeo) desse fitoplasma foi utilizado como sonda. Entretanto nem todos os isolados do fitoplasma associado ao enfezamento vermelho do milho contém DNA plasmidial, limitando a utilidade de tais sondas para a indexação dessa doença do milho. 
Os métodos sorológicos e de hibridização não fornecem informações para o estabelecimento de relações genéticas entre os fitoplasmas (Sinclair et al., 1996). Estes microorganismos podem ser simultaneamente detectados e identificados usando-se PCR, cujos oligonucleotídeos permitem a amplificação das seqüências de DNA presentes em variantes pertencentes a grupos distintos. O uso de pares de oligonucleotídeos rmar diagnoses preliminares, baseadas em sintomas, ou a suspeita de presença de fitoplasmas em infecções isoladas ou mistas (Gundersen \& Lee, 1996). Esses oligonucleotídeos baseiam-se no gene 16SRNA. Esse gene foi escolhido por possuir uma seqüência básica conservada com algumas regiões variáveis, sendo ideal para estudos filogenéticos. Para análises comparativas, o 16SRNA possui características fundamentais como a universalidade e também a estabilidade dentro do genoma destes microrganismos.

Vários pares de oligonucleotídeos já foram desenvolvidos para deteç̧ão de fitoplasmas. Particularmente, para o enfezamento vermelho do milho, Harrison et al. (1996) construíram um par de oligonucleotídeos específico que se mostrou altamente solados provenientes da Flórida, Texas, Costa Rica e México. A especificidade destes oligonucleotídeos, entretanto, não foi confirmada para amostras de plantas coletadas no Brasil. Neste caso, o uso de oligonucleotídeos não do fitoplasma num número maior de amostras provenientes de plantas sintomáticas quando comparado com os oligonucleotídeos específicos (Bedendo, 1997; Lopes et al., 1997). Essa deteç̧ão diferenciada levou à suposição da ocorrência de diversidade genética entre os isolados de fitoplasmas presentes no milho (Bedendo, 1997), de forma idêntica à doença conhecida por amarelo da videira, onde já foram identificados quatro diferentes fitoplasmas associados á doença, variando com a procedência do material (Lee et al, 1995).

A identificação de fitoplasmas por PCR tem sido viabilizada através do emprego de oligonucleotídeos especificamente desenvolvidos para fitoplasmas pertencentes aos grupos I, III e V (Lee et al., 1994). A técnica envolve a aplicação de duplo PCR, onde o par universal de oligonucleotídeos R16 mF2/F1 é usado para a amplificação e os pares específicos são usados isoladamente para a reamplificação de 
fragmentos alvos de fitoplasmas pertencentes a estes três grupos (Lee et al., 1994). Nestes casos a detecção através de PCR já leva à identificação do fitoplasma.

A análise de RFLP tem sido comumente usada para a identificação de fitoplasmas diversos (Lee et al., 1993b; Lee et al., 1998). O método emprega enzimas de restrição para clivar os fragmentos de DNA amplificados pelo PCR. Cada enzima reconhece uma sequiência específica de nucleotídeos e corta os fragmentos de DNA originando fragmentos menores, os quais são separados através de eletroforese em gel de poliacrilamida. Para cada enzima é obtido um conjunto de bandas que caracteriza um perfil eletroforético. A análise comparativa destes perfis com padrões existentes na literatura permite a identificação de um fitoplasma no âmbito de grupo e subgrupo. 


\section{MATERIAL E MÉTODOS}

\section{- Coleta de amostras de milho.}

Folhas de milho exibindo sintomas de enfezamento vermelho foram coletadas em diferentes áreas de plantio comercial, localizadas no Estado de São Paulo, nos anos de 1995, 1996 e 1998.

Foi utilizado um total de 104 amostras, sendo 40 da região de Piracicaba, 20 de Barretos, 27 de Santa Cruz das Palmeiras e 17 de Guaíra. Para cada planta amostrada foram registrados os sintomas exibidos pela mesma. Os materiais de milho plantados nestas regiões pertenciam aos híbridos XL 510 (Braskalb), identificado por T6 e AG 951 (Agroceres) identificado por T1 e pipoca da variedade Zélia, identificada por P.

A partir de cada amostra foi obtido o DNA total para ser usado nos testes de PCR.

\section{- Extração de DNA, oligonucleotídeos e condições de PCR}

\section{- Extração}

A extração foi conduzida de acordo com a metodologia de Lee et al. (1993a), com pequenas modificações: Amostras de 0,3g para material seco ou $2 \mathrm{~g}$ de material fresco foram pulverizadas num almofariz com nitrogênio líquido. A seguir adicionou-se $15 \mathrm{~mL}$ de solução tampão de extração I e macerou-se o tecido e então se centrifugou por 20 minutos a 20000G. Após o descarte do sobrenadante ressuspendeurse o precipitado -se $100 \mu \mathrm{L}$ de proteinase $\mathrm{K}$ e

$550 \mu \mathrm{L}$ de Sarkosyl $10 \%$ (N-lauroyl sarcosine). O lisado foi incubado por uma hora a $55^{\circ}$ e centrifugado por 10 minutos a $7500 \mathrm{G}$. Salvourse o sobrenadante e a ele se juntou 0,6 volumes de isopropanol, mantendo-se o material a $-20^{\circ} \mathrm{C}$ por uma hora. Novamente 
se centrifugou a $12000 \mathrm{G}$ por 15 minutos, descartou-se o sobrenadante e ressuspendeutse o precipitado em $3 \mathrm{~mL}$ de solução tampão TE. Adicionouse $75 \mu \mathrm{L}$ de SDS $20 \%$ (lauryl sulfate-sodium dodecyl sulfate) e $60 \mu \mathrm{L}$ de proteinase $\mathrm{K}$ e incubourse por 30 minutos a $37^{\circ} \mathrm{C}$. Adicionou-se $525 \mu \mathrm{L}$ de solução $5 \mathrm{M}$ de $\mathrm{NaCl}$ e $420 \mu \mathrm{L}$ de $\mathrm{CTAB} / \mathrm{NaCl}(10 \%$ cetyltrimethylammonium bromide $/ 0,7 \mathrm{M} \mathrm{NaCl}$ ) e incubourse por 10 minutos a $65^{\circ} \mathrm{C}$. Juntou-se volume igual de clorofórmio (24 partes)/(1parte) álcool isoamílico (CIA), centrifugou-se por 5 minutos a $4000 \mathrm{G}$ e removeu-se a fase aquosa. Repetiu-se a extração com clorofórmio/álcool isoamílico; removeurse a fase aquosa e adicionourse igual volume de fenol/CIA. Levourse para centrifugação por 5 minutos a 4000G, transferiu-se a fase aquosa para novo tubo e adicionou-se 0,6 volumes de isopropanol. A mistura foi incubada por 30 minutos a $-20^{\circ} \mathrm{C}$ e centrifugada a $10000 \mathrm{G}$ por 20 minutos. $\mathrm{O}$ sobrenadante foi descartado e cobriu-se o precipitado com etanol $70 \%$. O material foi mantido no gelo por 30 minutos e centrifugado por 20 minutos a 10000G. Em seguida descartourse o álcool e secourse o precipitado com nitrogênio. $\mathrm{O}$ precipitado foi suspenso em $200 \mu \mathrm{L}$ de solução tampão TE e centrifugado novamente por 5 minutos a 5000G. Finalmente, transferiu-se a suspensão para microtubos plásticos que foram armazenados a $4^{\circ} \mathrm{C}$.

As soluções tampão foram preparadas da seguinte forma:

Solução tampão de extração I: $\mathrm{K}_{2} \mathrm{HPO}_{4} \cdot 3 \mathrm{H}_{2} \mathrm{O}$ - 21,7g; $\mathrm{KH}_{2} \mathrm{PO}_{4}$ - 4,1g; sacarose 100g; BSA (Bovine Serum Albumin) 1,5g; PVP-10 (PolyVinylPyrolidone) 20g; água para completar o volume para um litro. Esterilização por filtração e manutenção a $4^{\circ} \mathrm{C}$.

Solução tampão de extração II: Tris-base 6g; NaCl 7,3g; EDTA 18,6g; pH 8; água para completar volume para $0,5 \mathrm{~L}$. Esterilização por autoclavagem e manutenção a temperatura ambiente.

Solução tampão TE: Tris-base 60,5g; EDTA 18,6g, pH 8; água para completar volume para 0,5L. Esterilização por autoclavagem e manutenção a temperatura ambiente. 


\section{- Oligonucleotíeos}

Para detecção do fitoplasma foram usados dois pares de oligonucleotídeos ("primers") universais mF2/R1- F2n1R2 (Gundersen \& Lee, 1996) em PCR duplo. Para deteç̧ão específica do fitoplasma do enfezamento vermelho do milho foi usado o par de oligonucleotídeos MBS F1/R1 (Harrison et al., 1996) em PCR simples, cujas sequiências encontram-se a seguir:

\section{Oligonucleotídeos universais:}

Oligonucloetídeo R16mF2/R1

- R16mF2- 5' cat gca agt cga acg a 3'

- R16mR1 -5' ctt aac ccc aat cat cga C 3'

Oligonucleotídeo R16F2n1R2

- R16F2n- 5' gaa acg act gct aag act gg 3'

- R16R2 -5' tga cgg geg gtg tgt aca aac ccc 93'

\section{Oligonucleotídeos específicos:}

Oligonucleotídeos MBS F1/R1

- MBS Fl -5' aat gtc gaa cta aca ggc gg 3'

- $\quad$ MBS R1- 5' ttg gcg att tgg ttt tgg 3'

Para a identificação de fitoplasma através de PCR, foram usados os pares específicos para grupo I e grupo II e grupo V em PCR duplo (Lee et al., 1994). O par mF2/R1 foi utilizado na primeira reação. Os produtos foram diluídos a 1:50 e reamplificados pelos pares específicos, isoladamente. A seguir as seqiiências dos oligonucleotídeos específicos:

Oligonucleotídeo específico 12ara o grupo I: RI6(I)F1/R1

- R16(I)F1 -5' taa aag acc tag caa tag g 3 ,

- R16(I)R1 - 5' caa tcc gaa ctg aga ctg t 3' 
Oligonucleotídeo específico para o grupo III: RI6(III)F2/R1

- RI6(III)F2 -5' aag agt gga aaa act ccc 3'

- RI6(III)R1 -5' tcc gaa ctg aga ttg a 3'

Oligonucleotídeo específico para o grupo V: RI6(V)F2/R1

- RI6(V)F2- 5' tta aaa aga ctt ctt cgg 3'

- RI6(V)R1-5' ttc aat ccg tac tga gac tac c 3'

- Condições de PCR, padrões e marcador molecular

As reações de PCR com oligonucleotídeos universais foram conduzidas com volume final de $25 \mu \mathrm{L}$, seguindo a metodologia de Lee et al. (1993b), possuindo os seguintes componentes: $19 \mu \mathrm{L}$ de água deionizada-destilada; $0,5 \mu \mathrm{L}$ de cada oligonucleotídeo (solução $20 \mathrm{pmol} / \mu \mathrm{L}$ ); $2 \mu \mathrm{L}$ de solução de dideoxinucleotídeos (solução $2,5 \mathrm{mM}$ de cada dideoxinucleotídeo); $2,5 \mu \mathrm{L}$ de tampão PCR; 0,15 $\mu \mathrm{L}$ de Amplitaq 5U/ $\mu 1$ (Perkin Elmer Co.,Norwalk, CT); 1-2 $\mu \mathrm{L}$ de DNA extraído da planta $(25 \mathrm{n} / \mu \mathrm{L})$. As reações foram processadas em um aparelho termociclador automático programado para 35 ciclos, sendo que cada ciclo compreendeu uma etapa de denaturação ( $94^{\circ} \mathrm{C}$ por um minuto), de anelamento $\left(50^{\circ} \mathrm{C}\right.$ por dois minutos) e de extensão $\left(72^{\circ} \mathrm{C}\right.$ por três minutos), além de uma etapa inicial de desnaturação por dois minutos e uma etapa final de extensão por sete minutos.

As reações de PCR com oligonucleotídeos específicos foram conduzidas conforme a metodologia de Harrison et al., (1996), em um volume final de reação de $25 \mu \mathrm{L}$, contendo $19 \mu \mathrm{L}$ de água deionizada-destilada; 0,5 $\mu \mathrm{L}$ de cada oligonucleotídeo (solução estoque de $50 \mathrm{ng} / \mu \mathrm{L}$ ); $2 \mu \mathrm{L}$ de uma mistura de dideoxinucleotídeos (solução estoque de $0,781 \mathrm{mM}$ de cada dideoxinucleotídeo); 2,5 $\mu \mathrm{L}$ de tampão PCR (idem descrito anteriormente); 0,10 $\mu \mathrm{L}$ de Amplitaq 5U/uL (Perkin Elmer Co., Norwalk, CT), 1-2 $\mu$ L de DNA extraído da planta. As reações foram processadas em termociclador programado para 40 ciclos, compreendendo desnaturação $\left(94^{\circ} \mathrm{C}\right.$ por 30 segundos), anelamento ( $61^{\circ} \mathrm{C}$ por 50 segundos ) e extensão $\left(72^{\circ} \mathrm{C}\right.$ por 80 segundos $)$, com uma 
etapa inicial de desnaturação por 90 segundos e uma etapa final de extensão por cinco minutos.

Como na metodologia de Harrison ocorreram problemas para amplificação procedeu-se novas reações de PCR com os oligonucleotídos específicos MBS R1/F1, mas utilizando-se as condições de amplificação descritas por Lee et al. (1993b).

Os produtos de PCR foram analisados em gel de agarose a 1\%, após a eletroforese por 90 minutos, 65 volts em tampão 1xTA. Após coloração com brometo de etídeo, o gel foi observado em um transiluminador de luz ultravioleta.

O marcador molecular usado foi $1 \mathrm{~kb}$ ladder (Life Technologies). Como padrão positivo foi usado DNA de planta de milho sabidamente doente. Como padrão negativo, DNA de planta de milho sadia e água destilada deionizada em substituição ao DNA

\section{- Análise de RFLP}

A identificação dos isolados também foi feita através da técnica de RFLP, com base nas análises das seqüências do 16SrDNA amplificadas pelo PCR e digeridas com endonucleases (Lee et al, 1998). Alguns isolados representativos de cada região foram selecionados e submetidos a RFLP, como especificado no item resultados.

Após as amplificações dos fragmentos nas reações de duplo PCR, conduzido com os oligonucleotídeos universais $(\mathrm{mF} 2 / \mathrm{R} 1-\mathrm{F} 2 \mathrm{n} / \mathrm{R} 2)$, foi tomada uma alíquota de 3 a $5 \mu \mathrm{L}$ de cada produto de PCR, a qual foi digerida individualmente com cada enzima, por 30 horas a $36^{\circ} \mathrm{C}$, seguindo as recomendações dos fabricantes. As seguintes enzimas foram utilizadas: Alul, MseI, KpnI, Hhal, Rsal.

Os produtos da digestão foram analisados através de eletroforese em gel de poliacrilamida $4,5 \%$, seguida de coloração com brometo de etídeo e visualização em transiluminador de ultravioleta. O marcador molecular utilizado foi $\Phi$ X174RFHaeIII (Life Technologies). O perfil eletroforético obtido para cada amostra foi comparado com os padrões relatados no artigo de Lee et al (1998), para a identificação do fitoplasma e sua classificação em um dos catorze grupos atualmente reconhecidos para estes organismos. 


\section{RESULTADOS E DISCUSSÃO}

Os sintomas registrados para as plantas amostradas são semelhantes àqueles geralmente descritos para o enfezamento do milho (Nault, 1980, Shurtleff, 1986, Bedendo, 1999). No campo, os sintomas predominantes se caracterizaram por clorose marginal das folhas seguida de avermelhamento, redução na altura de plantas, proliferação de espigas mal formadas e enfezamento generalizado das plantas. Estes sintomas variaram quanto à intensidade dependendo da planta amostrada, sendo observado também que estes sintomas podiam ocorrer de forma isolada ou em diversas combinações, como relatado por Toffanelli \& Bedendo (2001). A maior ou menor intensidade de sintomas depende de uma série de fatores, entre eles época de infecção da planta, constituição genética do hospedeiro e população infectiva do vetor (Nault, 1980; Massola et al., 1999; Toffanelli, 2001; Toffanelli \& Bedendo, 2001)

Dentre as 104 amostras avaliadas, fitoplasma foi detectado em 69 delas, através de PCR duplo, utilizando os pares de oligonucleotídeos universais para fitoplasmas (Quadros 1, 2, 3, 4). A presença de fitoplasma foi evidenciada pela visualização de bandas, no gel de agarose, correspondentes à aproximadamente 1,2kb, bandas estas típicas para fitoplasmas quando se utiliza o referido par de oligonucleotídeos (Gundersen \& Lee, 1996). Resultados positivos foram obtidos para o padrão positivo representado pelo milho infectado, porém nenhuma amplificação ocorreu para os padrões negativos constituídos por plantas sadias e pela água. A detecção de fitoplasma em praticamente $70 \%(66,6 \%)$ das amostras testadas pode ser considerada alta, sendo que a não detecção de fitoplasmas em plantas apresentando sintomas tipicamente associados a eles não é fato raro. Isto pode ser atribuído à ocorrência de substâncias presentes nos extratos de tecidos vegetais que inibem a amplificação do fragmento de DNA alvo, à distribuição 
errática do fitoplasma na planta e mesmo ao baixo título do microrganismo nos tecidos vegetais (Liao \& Chen, 1980, Lee et al., 1994).

Os testes conduzidos com duplo PCR usando o par de oligonucleotídeos específicos para identificação de fitoplasmas do grupo I demonstraram a presença de fitoplasma em 53 amostras de plantas sintomáticas coletadas no campo (Quadros 1, 2, 3, 4). Nas amostras positivas, a presença do fitoplasma foi demonstrada pela de bandas típicas de aproximadamente 1,2kb (Lee et al., 1994). Fitoplasma foi detectado no controle positivo, representado por material de milho sabidamente doente, porém sua ausência foi demonstrada em plantas sadias e água, utilizadas como $\mathrm{p}$

Quando comparados com os oligonucleotídeos universais, os oligonucleotídeos específicos para identificação de fitoplasmas do grupo I se mostraram menos eficientes em amplificar as seqüências de DNA usadas como moldes nas reações de PCR. Ito ficou claramente demonstrado, pois os oligonucleotídeos universais detectaram fitoplasma em 69 amostras, enquanto aqueles específicos evidenciaram a presença de fitoplasma em 53 das 104 plantas amostradas.

Fitoplasmas pertencentes aos grupos III e V não foram constatados nas amostras avaliadas, pois nenhuma amplificação ocorreu quando os oligonucleotídeos específicos para identificação de fitoplasmas dos grupos III e V foram empregados em PCR duplo (Quadros 1, 2, 3, 4).

O fitoplasma associado ao enfezamento vermelho tem sido identificado como um membro do grupo I, tanto em materiais de milho plantados na América do Norte como em variedades e híbridos cultivados no Brasil. (Gundersen et al., 1996; Bedendo et al, 1997; Barros, 1997; Lee et al., 1998). No entanto, relatos feitos por Barros (1997) levantaram a suspeita da ocorrência de isolados pertencentes a um grupo distinto do grupo I, provavelmente representantes do grupo III. Os resultados obtidos neste trabalho confirmam os relatos de que o fitoplasma do enfezamento vermelho é um membro do grupo I, pois nenhum dos isolados avaliados foi detectado pelos oligonucleotídeos especificamente desenvolvidos para a identificação de fitoplasmas do grupo III.

Oligonucleotídeos específicos para detecção de fitoplasmas do grupo I foram utilizados por se saber previamente que o fitoplasma do enfezamento vermelho pertencia 
a este grupo. Por outro lado, o par desenvolvido para detecção de fitoplasmas do grupo III foi escolhido pelo fato de existir a suspeita de que fitoplasma deste grupo pudesse também estar envolvido com o enfezamento do milho. A grande maioria dos fitoplasmas conhecidos até o momento se enquadra nos grupo I e III, sendo que em número de representantes, o grupo III é superado somente pelo grupo I (Lee et al., 1998). Portanto, o uso destes dois pares de oligonucleotídeos teria uma ampla abrangência em termos de permitir a detecção de fitoplasmas nas amostras de milho. O par específico para detecção de fitoplasmas do grupo $\mathrm{V}$ foi utilizado tentativamente em disponibilidade do mesmo e da rapidez da técnica de PCR na análise dos isolados testados neste trabalho.

O emprego do par de oligonucleotídeos MBSF1/R1, especificamente desenvolvido para detecção do fitoplasma associado ao enfezamento do milho, demonstrou a presença de fitoplasma em 49 amostras (Quadros 1, 2, 3, 4). A presença do fitoplasma foi constatada pela visualização de bandas correspondentes à aproximadamente $740 \mathrm{pb}$, bandas estas características para o fitoplasma do milho, quando se utiliza este par específico (Harrison et al., 1996). Na amostra usada como padrão positivo, representado por planta doente de milho, também foi visualizada banda típica, porém nenhuma amplificação ocorreu para os padrões negativos constituídos por planta sadia e pela água. Também neste caso, os oligonucleotídeos específicos apresentaram menor eficiência de detecção em relação aos oligonucleotídeos universais. Este tipo de resultado também foi obtido por Bedendo (1997), o qual relatou maior do fitoplasma do enfezamento com os oligonucleotídeos universais do que com os específicos.

Neste caso, as condições de PCR utilizadas foram aquelas descritas por Lee et al. (1993b), pois nas condições indicadas por Harrison et al. (1996) os resultados demonstraram a ocorrência de fitoplasma em pouquíssimas amostras. 


\begin{tabular}{|c|c|c|c|c|c|c|}
\hline Amostra & $\begin{array}{l}\text { Híbrido/ } \\
\text { Variedade }\end{array}$ & $\begin{array}{c}\text { Oligonucleotídeos } \\
\text { Universais }\end{array}$ & $\begin{array}{c}\text { Oligonucleotídeo } \\
\text { Específico }\end{array}$ & $\begin{array}{c}\text { Oligonucleotídeo } \\
\text { Grupo I }\end{array}$ & $\begin{array}{c}\text { Oligonucleotídeo } \\
\text { Grupo III }\end{array}$ & $\begin{array}{c}\text { Oligonucleotídeo } \\
\text { Grupo V }\end{array}$ \\
\hline 398 & $\mathrm{~T} 6$ & - & & + & - & - \\
\hline 399 & T6 & + & + & + & - & - \\
\hline 400 & T6 & + & + & + & - & - \\
\hline 401 & T6 & - & + & + & - & - \\
\hline 402 & T6 & + & + & + & - & - \\
\hline 403 & T6 & + & + & + & - & - \\
\hline 404 & T6 & + & - & - & - & - \\
\hline 405 & T6 & + & - & + & - & - \\
\hline 407 & $\mathrm{~T} 6$ & + & + & + & - & - \\
\hline 408 & T6 & + & + & - & - & - \\
\hline 409 & T6 & + & + & - & - & - \\
\hline 410 & T6 & - & - & - & - & - \\
\hline 411 & $\mathrm{~T} 6$ & + & - & - & - & - \\
\hline 412 & $\mathrm{~T} 6$ & - & + & + & - & - \\
\hline 413 & T6 & + & + & + & - & - \\
\hline 414 & T6 & + & + & + & - & - \\
\hline 415 & T6 & + & + & + & - & - \\
\hline
\end{tabular}

Quadro 1. Amostras obtidas de plantas de milho coletadas na região de Guaíra, apresentando sintomas de enfezamento vermelho, submetidas a PCR com diferentes oligonucleotídeos para detecção ou identificação do fitoplasma associado à (As células destacadas em cores correspondem a resultados positivos na amplificação de acordo com os oligonucleotídeos utilizados). 


\begin{tabular}{|c|c|c|c|c|c|c|}
\hline Amostra & $\begin{array}{l}\text { Híbrido/ } \\
\text { Variedade }\end{array}$ & $\begin{array}{c}\text { Oligonucleotídeos } \\
\text { Universais }\end{array}$ & $\begin{array}{c}\text { Oligonucleotídeo } \\
\text { Específico }\end{array}$ & $\begin{array}{c}\text { Oligonucleotídeo } \\
\text { Grupo I }\end{array}$ & $\begin{array}{c}\text { Oligonucleotídeo } \\
\text { Grupo III }\end{array}$ & $\begin{array}{c}\text { Oligonucleotídeo } \\
\text { Grupo V }\end{array}$ \\
\hline 39 & $\mathrm{~T} 6$ & + & - & - & - & - \\
\hline 40 & T6 & - & - & + & - & - \\
\hline 79 & T6 & + & - & - & - & - \\
\hline 80 & $\mathrm{~T} 1$ & + & - & + & - & \\
\hline 81 & $\mathrm{~T} 1$ & + & + & + & - & - \\
\hline 86 & T6 & + & + & + & - & - \\
\hline 88 & T6 & + & - & + & - & - \\
\hline 90 & $\mathrm{~T} 1$ & - & - & + & - & - \\
\hline 92 & $\mathrm{~T} 6$ & - & + & - & - & - \\
\hline 96 & T6 & + & + & + & - & - \\
\hline 105 & $\mathrm{~T} 1$ & + & - & - & - & - \\
\hline 106 & $\mathrm{~T} 1$ & - & - & - & - & - \\
\hline 107 & $\mathrm{~T} 1$ & - & - & - & - & - \\
\hline 110 & $\mathrm{~T} 1$ & - & + & + & - & - \\
\hline 111 & $\mathrm{~T} 1$ & - & - & - & - & - \\
\hline 118 & $\mathrm{~T} 1$ & - & - & - & - & - \\
\hline 115 & $\mathrm{~T} 1$ & + & - & - & - & - \\
\hline 120 & $\mathrm{~T} 1$ & + & + & - & - & - \\
\hline 126 & T6 & - & - & - & - & - \\
\hline 128 & T6 & - & - & - & - & - \\
\hline 149 & $\mathrm{~T} 1$ & - & - & - & - & - \\
\hline 150 & $\mathrm{~T} 1$ & - & - & - & - & - \\
\hline 151 & $\mathrm{~T} 1$ & - & - & - & - & - \\
\hline 227 & T6 & - & - & - & - & - \\
\hline 491 & $\mathrm{~T} 1$ & + & + & + & - & - \\
\hline 497 & $\mathrm{~T} 1$ & + & + & + & 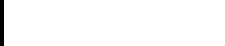 & \\
\hline 498 & $\mathrm{~T} 1$ & + & + & + & - & - \\
\hline 499 & $\mathrm{~T} 1$ & - & + & + & - & - \\
\hline 500 & $\mathrm{~T} 1$ & - & - & + & & \\
\hline
\end{tabular}




\begin{tabular}{|c|c|c|c|c|c|c|}
\hline Amostra & $\begin{array}{l}\text { Híbrido/ } \\
\text { Variedade }\end{array}$ & $\begin{array}{c}\text { Oligonucleotídeos } \\
\text { Universais }\end{array}$ & $\begin{array}{c}\text { Oligonucleotídeo } \\
\text { Específico }\end{array}$ & $\begin{array}{c}\text { Oligonucleotídeo } \\
\text { Grupo I }\end{array}$ & $\begin{array}{c}\text { Oligonucleotídeo } \\
\text { Grupo III }\end{array}$ & $\begin{array}{c}\text { Oligonucleotídeo } \\
\text { Grupo V }\end{array}$ \\
\hline 501 & $\mathrm{~T} 1$ & - & + & - & & \\
\hline 502 & $\mathrm{~T} 1$ & + & + & + & & \\
\hline 503 & $\mathrm{~T} 1$ & + & + & + & - & - \\
\hline 508 & $\mathrm{~T} 1$ & + & + & + & - & - \\
\hline 509 & $\mathrm{~T} 1$ & + & + & + & - & - \\
\hline 510 & $\mathrm{~T} 1$ & + & + & + & - & - \\
\hline 511 & $\mathrm{~T} 1$ & + & + & - & - & - \\
\hline CL 1 & $\mathrm{P}$ & - & + & + & - & - \\
\hline CL 2 & $\mathrm{P}$ & + & + & + & - & - \\
\hline CL 3 & $\mathrm{P}$ & - & - & - & - & - \\
\hline CL 4 & $P$ & + & - & - & - & - \\
\hline
\end{tabular}

Quadro 2. Amostras obtidas de plantas de milho coletadas na região de Piracicaba, apresentando sintomas de enfezamento vermelho, submetidas a PCR com diferentes oligonucleotídeos para detecção ou identificação do fitoplasma associado à doença. (As células destacadas em cores correspondem a resultados positivos na amplificação de acordo com os oligonucleotídeos utilizados). 


\begin{tabular}{|c|c|c|c|c|c|c|}
\hline Amostra & $\begin{array}{l}\text { Híbrido/ } \\
\text { Variedade }\end{array}$ & $\begin{array}{c}\text { Oligonucleotídeos } \\
\text { Universais }\end{array}$ & $\begin{array}{c}\text { Oligonucleotídeo } \\
\text { Específico }\end{array}$ & $\begin{array}{c}\text { Oligonucleotídeo } \\
\text { Grupo I }\end{array}$ & $\begin{array}{c}\text { Oligonucleotídeo } \\
\text { Grupo III }\end{array}$ & $\begin{array}{c}\text { Oligonucleotídeo } \\
\text { Grupo V }\end{array}$ \\
\hline 140 & $\mathrm{~T} 6$ & + & - & - & - & - \\
\hline 144 & $\mathrm{~T} 1$ & - & & & - & - \\
\hline 330 & $\mathrm{~T} 1$ & - & + & + & - & - \\
\hline 332 & $\mathrm{~T} 1$ & + & + & + & - & - \\
\hline 334 & T6 & + & + & - & - & - \\
\hline 335 & T6 & + & - & + & - & - \\
\hline 336 & T6 & - & + & + & - & - \\
\hline 337 & T6 & + & - & - & - & - \\
\hline 339 & T6 & + & - & - & - & - \\
\hline 340 & T6 & + & + & + & - & - \\
\hline 341 & T6 & + & + & + & - & - \\
\hline 342 & T6 & + & + & - & - & - \\
\hline 343 & T6 & + & - & + & - & - \\
\hline 345 & T6 & - & + & - & - & - \\
\hline 346 & T6 & + & - & + & - & - \\
\hline 348 & T6 & + & - & - & - & - \\
\hline 349 & T6 & + & + & - & - & - \\
\hline 350 & $\mathrm{~T} 6$ & + & - & - & - & - \\
\hline 350 & T6 & + & - & - & - & - \\
\hline 352 & T6 & - & - & - & - & - \\
\hline 353 & T6 & + & - & - & - & - \\
\hline
\end{tabular}

Quadro 3. Amostras obtidas de plantas de milho coletadas na região de Barretos, apresentando sintomas de enfezamento vermelho, submetidas a PCR com diferentes oligonucleotídeos para detecção ou identificação do fitoplasma associado à doença. (As células destacadas em cores correspondem a resultados positivos na amplificação de acordo com os oligonucleotídeos utilizados). 


\begin{tabular}{|c|c|c|c|c|c|c|}
\hline Amostra & $\begin{array}{l}\text { Híbrido/ } \\
\text { Variedade }\end{array}$ & $\begin{array}{c}\text { Oligonucleotídeos } \\
\text { Universais }\end{array}$ & $\begin{array}{c}\text { Oligonucleotídeo } \\
\text { Específico }\end{array}$ & $\begin{array}{c}\text { Oligonucleotídeo } \\
\text { Grupo I }\end{array}$ & $\begin{array}{c}\text { Oligonucleotídeo } \\
\text { Grupo III }\end{array}$ & $\begin{array}{c}\text { Oligonucleotídeo } \\
\text { Grupo V }\end{array}$ \\
\hline 269 & $\mathrm{~T} 1$ & - & - & - & - & - \\
\hline 270 & $\mathrm{~T} 1$ & + & - & - & - & - \\
\hline 275 & $\mathrm{~T} 1$ & - & - & + & - & - \\
\hline 276 & $\mathrm{~T} 1$ & + & - & + & - & - \\
\hline 278 & $\mathrm{~T} 1$ & + & + & + & - & - \\
\hline 279 & $\mathrm{~T} 1$ & + & - & - & - & - \\
\hline 280 & $\mathrm{~T} 1$ & + & - & - & - & - \\
\hline 282 & $\mathrm{~T} 1$ & - & - & - & - & - \\
\hline 293 & $\mathrm{~T} 6$ & - & + & + & - & - \\
\hline 294 & T6 & + & + & + & - & - \\
\hline 295 & T6 & - & + & + & - & - \\
\hline 296 & $\mathrm{~T} 6$ & + & - & + & - & - \\
\hline 297 & T6 & + & - & - & - & - \\
\hline 298 & $\mathrm{~T} 6$ & + & + & + & - & - \\
\hline 299 & T6 & + & + & - & - & - \\
\hline 300 & $\mathrm{~T} 6$ & + & + & + & - & - \\
\hline 301 & T6 & + & - & + & - & - \\
\hline 302 & T6 & + & - & - & - & - \\
\hline 303 & T6 & + & - & + & - & - \\
\hline 305 & T6 & - & + & - & - & - \\
\hline 306 & T6 & + & - & - & - & - \\
\hline 307 & T6 & - & - & - & - & - \\
\hline 308 & T6 & + & - & - & - & - \\
\hline 309 & $\mathrm{~T} 6$ & + & - & - & - & - \\
\hline 310 & T6 & + & - & + & - & - \\
\hline 311 & $\mathrm{~T} 6$ & + & - & - & - & - \\
\hline 319 & T6 & + & + & + & - & - \\
\hline
\end{tabular}

Quadro 4. Amostras obtidas de plantas de milho coletadas na região de Santa Cruz das Palmeiras, apresentando sintomas de enfezamento vermelho, submetidas a PCR com diferentes oligonucleotídeos para detecção ou identificação do fitoplasma associado à doença. (As células destacadas em cores correspondem a resultados positivos na amplificação de acordo com os oligonucleotídeos utilizados). 
Para análise de RFLP foram escolhidos, ao acaso, 29 isolados abrangendo as quatro regiões de coleta (Quadros 5, 6, 7, 8), sendo todos detectados com os oligonucleotídeos universais. Destes 29 isolados, 15 foram também detectados com os oligonucleotídeos específicos para o grupo I e 15 com os oligonucleotídeos específicos para o fitoplasma do enfezamento vermelho do milho (Quadros 5, 6,7,8). Dentro deste grupo de 29 isolados, foi constituído um grupo de oito isolados que foram detectados exclusivamente pelos oligonucleotídeos universais, conforme relação abaixo. Para todos os 29 isolados submetidos à técnica de RFLP, a digestão enzimática foi sempre conduzida com os produtos do PCR duplo usando-se os pares de oligonucleotídeos mF2/R1-F2n/R2.

A seguir a relação dos isolados empregados nas análises de RFLP:

- Piracicaba: 81, 120, 491,502,508,509.

- Guaíra: 400, 405, 408, 409, 413.

- Barretos: 334, 340, 343, 346,349.

- Santa Cruz das Palmeiras: 278, 294, 301, 303, 306.

- Detecção somente através de oligonucleotíde os universais:

o Piracicaba: 79, 105.

o Santa Cruz das Palmeiras 279, 302, 311

o Barretos: 348.

o Guaíra: 404, 411. 


\begin{tabular}{|c|c|c|c|c|c|c|}
\hline \multicolumn{7}{|c|}{ Guaíra } \\
\hline Isolados & Hib/Var. & Universal & MBS 1 & Grupo I & Grupo III & Grupo V \\
\hline 400 & $\mathrm{~T} 6$ & + & + & + & - & - \\
\hline 404 & $\mathrm{~T} 6$ & + & - & - & - & - \\
\hline 405 & $\mathrm{~T} 6$ & + & - & + & - & - \\
\hline 408 & $\mathrm{~T} 6$ & + & + & - & - & - \\
\hline 409 & $\mathrm{~T} 6$ & + & + & - & - & - \\
\hline 411 & $\mathrm{~T} 6$ & + & - & - & - & - \\
\hline 413 & $\mathrm{~T} 6$ & + & + & + & & \\
\hline
\end{tabular}

Quadro 5. Isolados provenientes da regiāo de Guaira selecionados para análise de RFLP e sua detecçầo com os diferentes oligonucleotídeos. (As células destacadas em cores correspondem a resultados positivos na amplificação de acordo com os oligonucleotideos utilizados).

\begin{tabular}{|c|c|c|c|c|c|c|}
\hline \multicolumn{7}{|c|}{ Piracicaba } \\
\hline Iselados & Hib/Var. & Universal & MBS 1 & Grupo I & Grupo III & Grupo V \\
\hline 79 & $\mathrm{~T} 6$ & + & - & - & - & - \\
\hline 81 & $\mathrm{~T} 1$ & + & + & + & - & - \\
\hline 105 & $\mathrm{~T} 6$ & + & - & - & - & - \\
\hline 120 & $\mathrm{~T} 1$ & + & + & - & - & - \\
\hline 491 & $\mathrm{~T} 1$ & + & + & + & - & - \\
\hline 502 & $\mathrm{~T} 1$ & + & + & + & - & - \\
\hline 508 & $\mathrm{~T} 1$ & + & + & + & - & - \\
\hline 509 & $\mathrm{~T} 1$ & + & + & + & - & - \\
\hline
\end{tabular}

Quadro 6. Isolados provenientes da região de Piracicaba selecionados para análise de RFLP e sua deteç̧ầo com os diferentes oligonucleotideos. (As células destacadas $\mathrm{cm}$ cores correspondem a resultados positivos na amplificaçăo de acordo com os oligonucleotídeos utilizados). 


\begin{tabular}{|c|c|c|c|c|c|c|}
\hline \multicolumn{7}{|c|}{ Barretos } \\
\hline Isolados & Hib/Var. & Universal & MBS 1 & Grupo I & Grupo III & Grupo V \\
\hline 334 & T6 & + & + & - & - & - \\
\hline 340 & T6 & + & + & + & - & - \\
\hline 343 & T6 & + & - & + & - & - \\
\hline 346 & T6 & + & - & + & - & - \\
\hline 348 & T6 & + & - & - & - & - \\
\hline 349 & T6 & + & + & - & - & - \\
\hline
\end{tabular}

Quadro 7. Isolados provenientes da regiāo de Barretos selecionados para análise de RFLP e sua detecção com os diferentes oligonucleotideos. (As celulas destacadas em cores correspondem a resultados positivos na amplificação de acordo com os oligonucleotideos utilizados).

\begin{tabular}{|c|c|c|c|c|c|c|}
\hline \multicolumn{7}{|c|}{ Santa Cruz das Palmeiras } \\
\hline Isolados & Hib/Var. & Universal & MBS 1 & Grupo I & Grupo III & Grupo V \\
\hline 278 & T1 & + & + & + & - & - \\
\hline 279 & T1 & + & - & - & - & - \\
\hline 294 & T6 & + & + & + & - & - \\
\hline 301 & T6 & + & - & + & - & - \\
\hline 302 & T6 & + & - & - & - & - \\
\hline 303 & T6 & + & - & + & - & - \\
\hline 306 & T6 & + & - & - & & \\
\hline 311 & T6 & + & - & - & & \\
\hline
\end{tabular}

Quadro 8. Isolados provenientes da regiāo de Santa Cruz das Palmeiras selecionados para análise de RFLP e sua deteç̧āo com os diferentes oligonucleotideos. (As células destacadas em cores correspondem a resultados positivos na amplificação de acordo com os oligonucleotideos utilizados.) 
Dentre as enzimas de restrição, foram selecionadas para este trabalho as endonucleases Alu I, Kpn I, Mse I e Rsa I, Hha I, as quais têm sido utilizadas para distinção de fitoplasmas em grupos e subgrupos (Lee et al., 1998).

Quanto à identificação dos isolados para grupo, a enzima Kpn I foi empregada para distinguir fitoplasmas do grupo I daqueles pertencentes aos demais grupos conhecidos, exceção feita aos grupos XII e XIII, pois estes dois grupos apresentam os perfis eletroforéticos idênticos àqueles mostrados por representantes do grupo I. Para Kpn I, todos os isolados testados apresentaram perfis idênticos entre si e com aqueles relatados pela literatura para fitoplasmas do grupo I (Figura 1). A enzima Alu I permite distinguir fitoplasmas pertencentes ao grupo I dos fitoplasmas pertencentes aos demais grupos, exceção feita aos representantes do grupo XII. Portanto, o uso desta enzima além de identificar todos os isolados de milho testados neste ensaio como sendo pertencentes ao grupo I, excluiu a possibilidade da ocorrência de fitoplasma do grupo XIII em plantas de milho (Figura 2). Também neste caso, todos os isolados do milho apresentaram perfis idênticos entre si e com aqueles relatados pela literatura para fitoplasmas do grupo I. A enzima Mse I foi utilizada para separar fitoplasmas do grupo I daqueles pertencentes aos grupos XII e XIII. Mais uma vez, todos os isolados testados mostraram perfis eletroforéticos típicos do grupo I, sendo idênticos entre si (Figura 3). O emprego desta enzima demonstrou a ausência de fitoplasmas dos grupos XII e XIII em plantas de milho e confirmou a identificação de todos os isolados testados como sendo representantes do grupo I. A enzima Rsa I fornece um perfil eletroforético característico para fitoplasmas do grupo I, tendo sido utilizada por esta razão. Para Rsa I, os isolados de milho se apresentaram idênticos entre si e foram enquadrados dentro do grupo I, com base no perfil eletroforético apresentado (Figura 4).

Quanto à identificação dos isolados em subgrupo, todos os isolados testados apresentaram perfis eletroforéticos idênticos entre si e típicos do subgrupo B, para as enzimas Alu I, Mse I e Hha I. A enzima Mse I permite distinguir representantes do subgrupo B daqueles pertencentes aos subgrupos C e D. O emprego de Mse I confirmou que todos os isolados de milho testados eram representantes do subgrupo B, claramente distintos daqueles dos grupos $\mathrm{C}$ e $\mathrm{D}$, de acordo com os perfis eletroforéticos. A enzima 
de restrição Alu I se caracteriza por diferenciar representantes do subgrupo E, dos fitoplasmas pertencentes aos subgrupos C e E. O uso desta enzima permitiu demonstrar que todos os isolados testados apresentaram perfis típicos dos representantes do subgrupo B, evidenciando plena distinção dos representantes dos grupos C e E. A enzima Hha I possibilita diferenciar representantes do subgrupo B daqueles pertencentes aos subgrupos A e E. Os resultados obtidos com o emprego de Hha I confirmaram que todos os is olados testados pertenciam ao subgrupo B, sendo distintos dos representantes dos subgrupos A e E (Figura 5).

Através das digestões enzimáticas processadas com as enzimas de restrição ficou definitivamente confirmado o enquadramento dos isolados testados centro do grupo I. Ainda, os mesmos puderam ser identificados ao nível de subgrupo, se apresentando como representantes do subgrupo $\mathrm{B}$, de acordo com dos perfis eletroforéticos apresentados. Assim, os perfis eletroforéticos apresentados pelos isolados avaliados foram idênticos entre si, para cada uma das enzimas de restrição considerada individualmente. Os perfis obtidos para os isolados para as enzimas Alu I, Kpn I, Hha I, Mse I e Rsa I foram idênticos àqueles relatados na literatura para o fitoplasma do enfezamento do milho. Portanto, todos os 29 isolados identificados por RFLP se enquadraram no grupo I, subgrupo B da atual classificação de fitoplasmas (Lee et al. , 1998).

Neste trabalho, ficou demonstrado que os isolados identificados por PCR pertenciam unicamente ao grupo I, não ocorrendo amplificação, visualizada na forma de bandas, nos testes de PCR conduzidos com os pares de oligonucleotídeos específicos para identificação de fitoplasmas dos grupos III e V. A análise de RFLP confirmou os resultados obtidos no PCR, pois houve identidade entre os padrões de bandas apresentados pelos isolados testados com aqueles padrões típicos que caracterizam o fitoplasma do enfezamento vermelho. Todos os isolados analisados pela técnica de RFLP foram identificados como pertencentes ao subgrupo B do grupo I da classificação atualmente aceita para fitoplasmas, não tendo sido constatados a ocorrência de isolados pertencentes a qualquer um dos outros grupos atualmente conhecidos. 

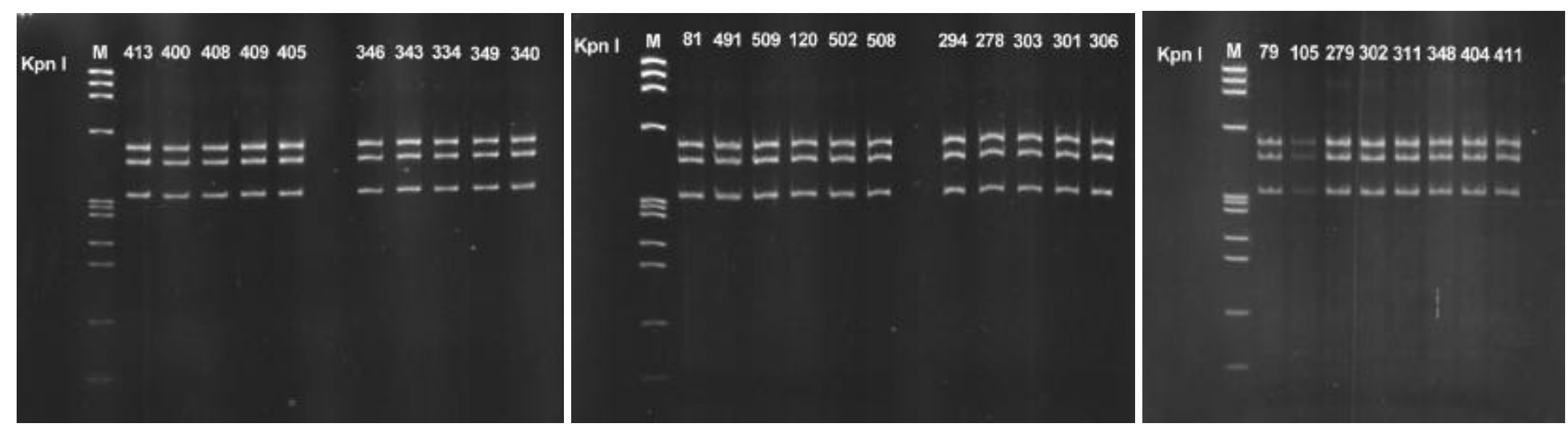

Figura 1 - Produtos da digestão enzimática com a endonuclease KpnI. Análise dos produtos de PCR duplo conduzido com os pares de oligonucleotídeos mF2/R1 e F2n/R2, utilizando DNA extraído de plantas de milho com sintomas de enfezamento, coletadas em quatro regiões do Estado de São Paulo: Guaíra (413, 400, 408, 409, 405,); Barretos (346, 343, 334, 349, 340); Piracicaba (81, 491, 509, 120, 502, 508); Santa Cruz das Palmeiras (294, 278, 303, 301, 306); e amostras positivas somente para o oligonucleotídeo universal nas 4 regiões: (Piracicaba: 79, 105; Santa Cruz das Palmeiras: 279, 302, 311; Barretos: 348; Guaíra: 404, 411). MM - padrão de peso molecular (de cima para baixo): 1353, 1078, 872, 603, 310, 281, 271, 234, 194,118 pb. 

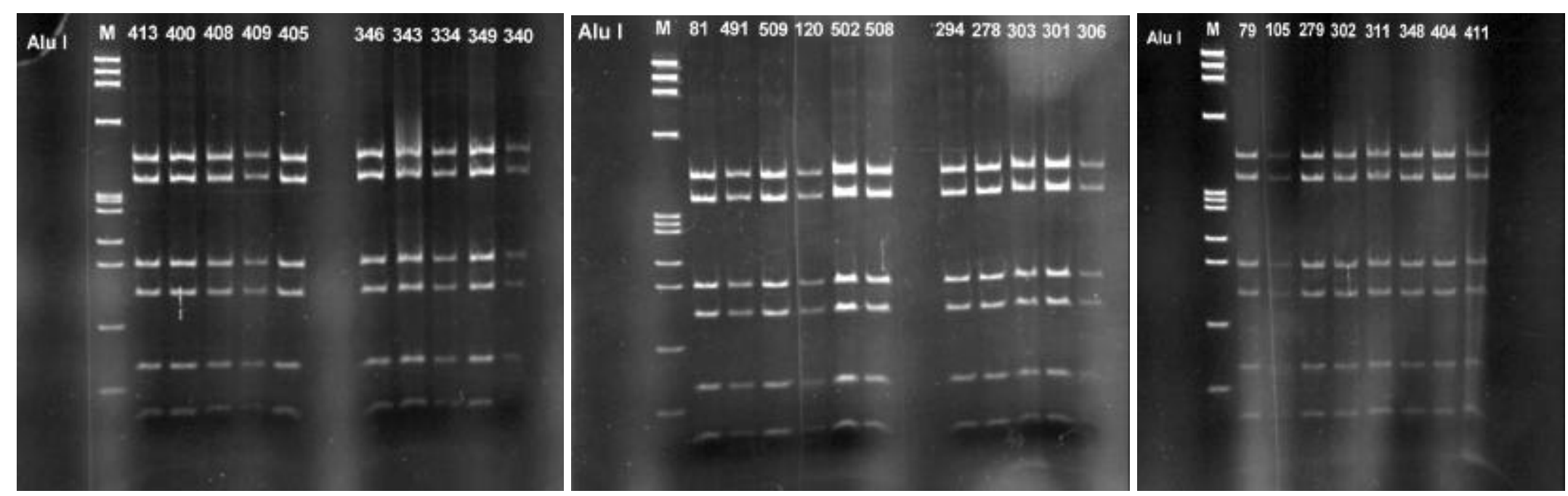

Figura 2 - Produtos da digestão enzimática com a endonuclease AluI. Análise dos produtos de PCR duplo conduzido com os pares de oligonucleotídeos mF2/R1 e F2n/R2, utilizando DNA extraído de plantas de milho com sintomas de enfezamento, coletadas em quatro regiões do Estado de São Paulo: Guaíra (413, 400, 408, 409, 405,); Barretos (346, 343, 334, 349, 340); Piracicaba (81, 491, 509, 120, 502, 508); Santa Cruz das Palmeiras (294, 278, 303, 301, 306); e amostras positivas somente para o oligonucleotídeo universal nas 4 regiões: (Piracicaba: 79, 105; Santa Cruz das Palmeiras: 279, 302, 311; Barretos: 348; Guaíra: 404, 411). MM - padrão de peso molecular (de cima para baixo): 1353, 1078, 872, 603, 310, 281, 271, 234, 194, 118 pb. 


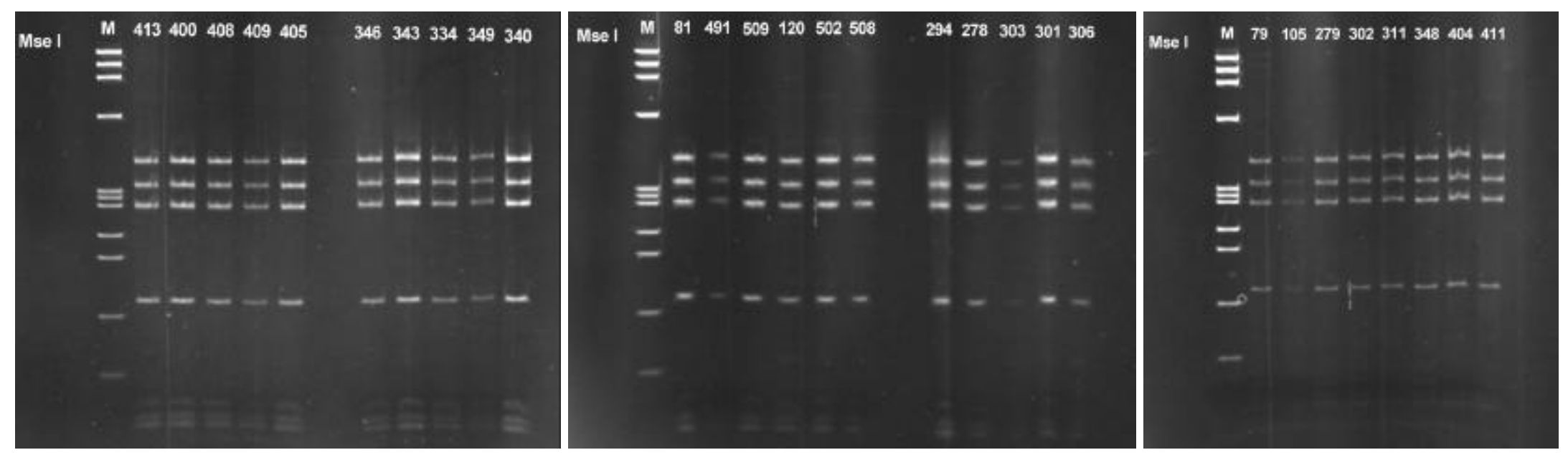

Figura 3 - Produtos da digestão enzimática com a endonuclease MseI. Análise dos produtos de PCR duplo conduzido com os pares de oligonucleotídeos mF2/R1 e F2n/R2, utilizando DNA extraído de plantas de milho com sintomas de enfezamento, coletadas em quatro regiões do Estado de São Paulo: Guaíra (413, 400, 408, 409, 405,); Barretos (346, 343, 334, 349, 340); Piracicaba (81, 491, 509, 120, 502, 508); Santa Cruz das Palmeiras (294, 278, 303, 301, 306); e amostras positivas somente para o oligonucleotídeo universal nas 4 regiões: (Piracicaba: 79, 105; Santa Cruz das Palmeiras: 279, 302, 311; Barretos: 348; Guaíra: 404, 411). MM - padrão de peso molecular (de cima para baixo): 1353, 1078, 872, 603, 310, 281, 271, 234, 194, 118 pb. 


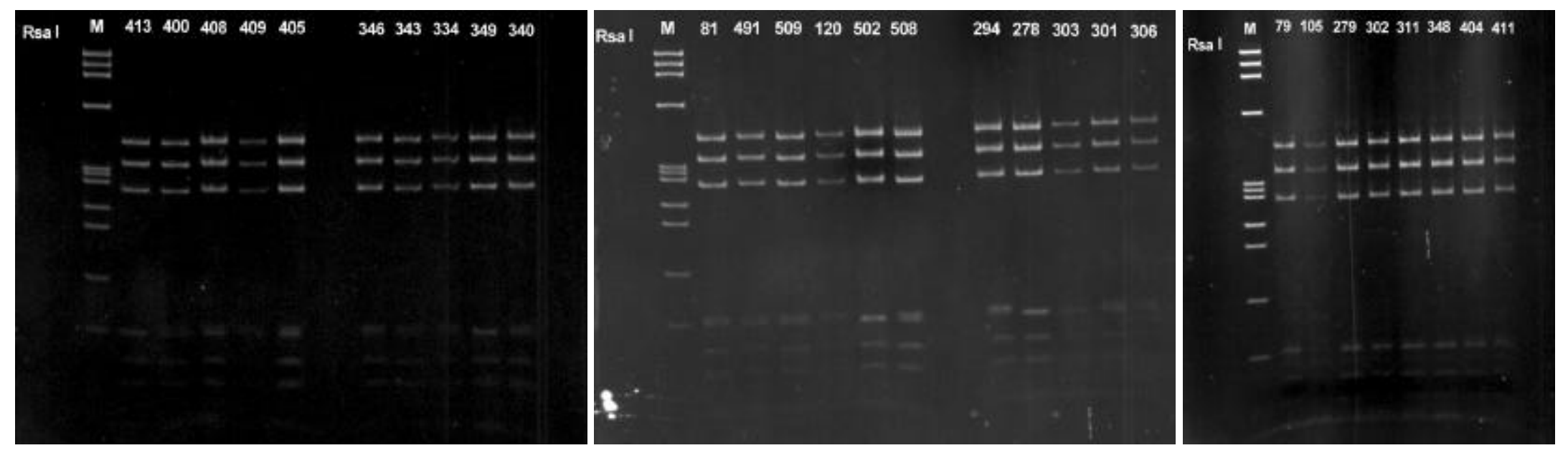

Figura 4 - Produtos da digestão enzimática com a endonuclease RsaI. Análise dos produtos de PCR duplo conduzido com os pares de oligonucleotídeos mF2/R1 e F2n/R2, utilizando DNA extraído de plantas de milho com sintomas de enfezamento, coletadas em quatro regiões do Estado de São Paulo: Guaíra (413, 400, 408, 409, 405,); Barretos (346, 343, 334, 349, 340); Piracicaba (81, 491, 509, 120, 502, 508); Santa Cruz das Palmeiras (294, 278, 303, 301, 306); e amostras positivas somente para o oligonucleotídeo universal nas 4 regiões: (Piracicaba: 79, 105; Santa Cruz das Palmeiras: 279, 302, 311; Barretos: 348; Guaíra: 404, 411). MM - padrão de peso molecular (de cima para baixo): 1353, 1078, 872, 603, 310, 281, 271, 234, 194, 118 pb. 


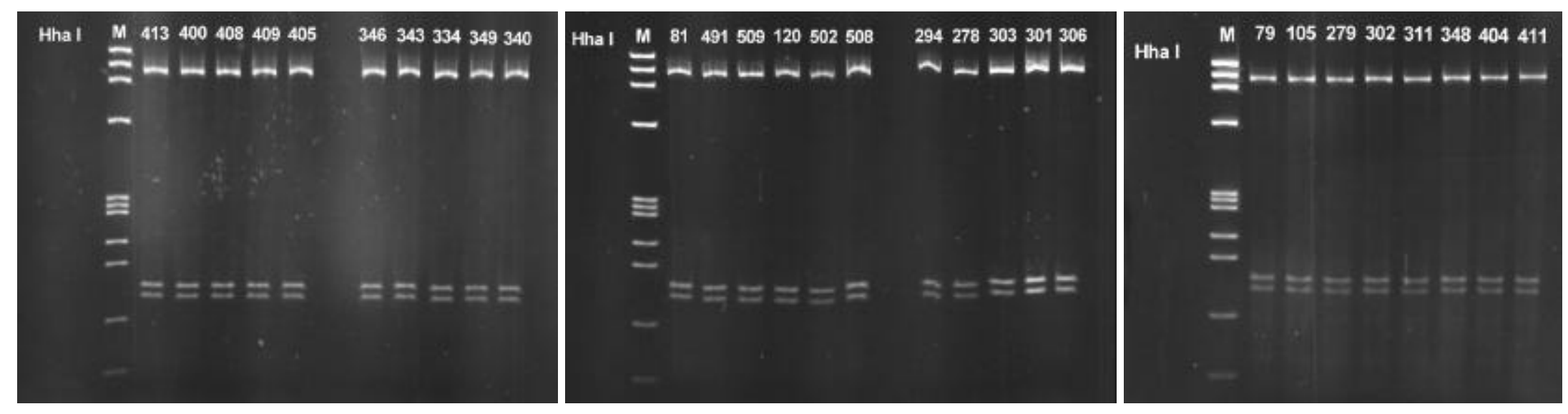

Figura 5 - Produtos da digestão enzimática com a endonuclease HhaI. Análise dos produtos de PCR duplo conduzido com os pares de oligonucleotídeos mF2/R1 e F2n/R2, utilizando DNA extraído de plantas de milho com sintomas de enfezamento, coletadas em quatro regiões do Estado de São Paulo: Guaíra (413, 400, 408, 409, 405,); Barretos (346, 343, 334, 349, 340); Piracicaba (81, 491, 509, 120, 502, 508); Santa Cruz das Palmeiras (294, 278, 303, 301, 306); e amostras positivas somente para o oligonucleotídeo universal nas 4 regiões: (Piracicaba: 79, 105; Santa Cruz das Palmeiras: 279, 302, 311; Barretos: 348; Guaíra: 404, 411). MM - padrão de peso molecular (de cima para baixo): 1353, 1078, 872, 603, 310, 281, 271, 234, 194,118 pb. 


\section{CONCLUSÕES}

- As análises de RFLP dos 29 isolados de fitoplasma associado ao enfezamento vermelho do milho demonstram que estes pertencem ao grupo I, subgrupo B.

- O resultado negativo obtido nos 69 isolados avaliados com o uso dos oligonucleotídeos específicos para grupos de fitoplasma (III e V), demonstra que não ocorrem fitoplasmas pertencentes a estes grupos

- A deteç̧ão dos fitoplasmas conduzidas com os oligonucleotídeos universais foi mais ampla comparada com a detecção dos oligonucleotídeos específicos, denotando uma maior sensibilidade dos oligonucleotídeos universais. 


\section{REFERÊNCIAS BIBLIOGRAFICAS}

BARROS, T.S.L. Fitoplasmas no Brasil: Caracterização molecular via "Polymerase chain reaction" e "Restriction length polymorphism". Brasília, 1997. 88p. Dissertação (Mestrado) - Instituto de Ciências Biológicas, Universidade de Brasília.

BEDENDO, I.P. Enfezamento vermelho e enfezamento pálido do milho associados a fitoplasma e espiroplasma: sintomatologia, etiologia e técnicas para detecção e identificação destes agentes. Summa Phytopathologica, v.25, p.190-196, 1999.

BEDENDO, I.P.; DAVIS, R.E.; DALLY, E.L. Detection and identification of the maize bushy stunt phytoplasma in corn plants in Brazil using PCR and RFLP. International Journal of Pest Management, v.46, p.73-76, 2000.

BEDENDO, I.P.; DAVIS, R.E.; DALLY, E.L. Molecular evidence for the presence of maize bushy stunt phytoplasma in corn in Brazil. Plant Disease, v.81, p.957. 1997.

BEDENDO, I.P. Deteç̧ão e identificação de fitoplasma, espiroplasma e vírus do "rayado fino" em plantas de milho, através de métodos moleculares Piracicaba, 1997. 69p. Tese (Livre-Docência) - Escola Superior de Agricultura "Luiz de Queiroz”, Universidade de São Paulo. 
BERTACCINI, A. First Internet conference on phytopatogenic mollicutes: phytoplasmas and yellows diseases. http://www.uniud.it/phytoplasma/pap/bert8310.html (20 ago. 2000).

BORGES, R.T.P.B. Método de seleção em milho para resistência da riscafitoplasma-espiroplasma. Piracicaba, 1997. 58p. Tese (Doutorado) - Escola Superior de Agricultura “Luiz de Queiroz”, Universidade de São Paulo.

CALAVAN, E.C.; BOVÉ, J.M. Ecology of Spiroplasma citri. In: WHITCOMB, R.F; TULLY, J.G. The mycoplasmas V: spiroplasmas, acholeplasmas, and mycoplasmas of plants and arthropods. San Diego: Academic Press, 1989. cap.9, p.425-477.

CHEN, T.A.; GRANADOS, R.R. Plant pathogenic mycoplasma-like organism: maintenance in vitro and transmission to Zea mays L. Science, v.167, p.1633$1636,1970$.

CHEN, T.A.; LIAO, C.H. Corn stunt spiroplasma: isolation, cultivation, and proof of pathogenicity. Science, v.188, p.1015-1017, 1975.

COSTA, A.S; KITAJIMA, E.W.; ARRUDA, S.C. Moléstias de vírus e de micoplasma do milho em São Paulo. Revista da Sociedade Brasileira de Fitopatologia, v.4, n.4, p.39-41, 1971.

DAVIS, R.E. Antibiotics sensitivities in vitro in diverse spiroplasma strains associated with plants and insects. Applied Environmental Microbiology, v.41, p.329-331, 1981.

DAVIS, R.E.; WORLEY, J.F.; WHITCOMB; R.F. ISHIMA. T.; STEERE, R.L. Helicoidal filaments produced by a mycoplasma-like organism associated with corn stunt disease. Science, v.176, p.521-523, 1972. 
DUDIENAS, C.; DUARTE, A.P.; PATERNIANI, M.E.; RIBEIRO, J.L.; BIANCHINI, M.T.; KANTHACH, R.A.; CASTRO, J.L.; SILVEIRA,L.C.; DENUCCI, S.; SABINO JÚNIOR, J.; BOLONHESI, D.; DE SORDI, G. Severidade de doenças no milho "safrinha" no Estado de São Paulo. In: SEMINÁRIO SOBRE A CULTURA DO MILHO "SAFRINHA”, 4., Assis, 1997. Anais. Assis: IAC,CVD, 1997. p. 107-115.

GARCIA, J.C. Evolução da área e produtividade do milho "safrinha” por estado. In: SEMINÁRIO SOBRE A CULTURA DO MILHO "SAFRINHA", 4., Assis, 1997. Anais. Assis: IAC,CVD, 1997. p.11-14.

GRANADOS, R.R. Electron microscopy of plants and insect vectors infected with the corn stunt disease agent. Contribution Boyce Thompson Institute, v.24, p.173-187, 1969.

GUNDERSEN, D.E.; LEE, I-M.; Ultrasensitive detection of phytoplasmas by nested-PCR assays using two universal primers pairs. Phytopathologia Mediterrânea, v.35, p.144-151, 1996

GUNDERSEN, D.E.; LEE, I-M.; SCHAFF, D.A.; HARRISON, N.A.; CHANG, C.J.; DAVIS, R.E.; KINGSBURY, D.T. Genomic diversity and differentiation among phytoplasma strains in 16 rRNA groups I (aster yellows and related phytoplasmas) and III (X-disease and related phytoplasmas). International Journal of Systematic Bacteriology, v.46, n.1, p.64-75, Jan. 1996

HARRISON, N.A.; RICHARDSON, P.A.; TSAI J.H. PCR Assay for detection of the phytoplasma associated with maize bushy stunt disease. Plant Disease, v.80, n.3, p.263-268, Mar. 1996. 
HRUSKA, A.J; GLADSTONE, S.M.; OBANDO, R. Epidemic roller coaster: Maize Stunt Disease in Nicarágua. American Entomologist, v.42, n.4, p.248-252, 1996.

KITAJIMA, E.W.; COSTA, A.S. Micoplasma: possível agente etiológico de certas moléstias de plantas. Revista Ciência e Cultura, v.22, p.351-363, 1970.

KUNKEL, L.O. Leafhopper transmission of corn stunt. Proceedings of the National Academy of Science of the USA, v.32, p.246-247, 1946.

LEE, HM.; BERTACCINI, A.; VIBIO, M.; GUNDERSEN, D.E. Detection of multiple phytoplasmas in perennial fruit trees with decline symptoms in Italy. Phytopathology, v.85, n.6, p.728-735, 1995.

LEE, FM.; DAVIS, R.E.; SINCLAIR, W.A.; De WITT, N.D.; CONTI, M. Genetic relatedness of mycoplasmalike organisms detected in Ulmus spp. in the United States and Italy by means of DNA probes and polymerase chain reaction. Phytopathology, v.83, p.892-833, 1993a.

LEE, I-M.; HAMMOND, R.W.; DAVIS, R.E.; GUNDERSEN, D.E. Universal amplification and analysis of pathogen 16SrDNA for classification and identification of mycoplasmalike organisms. Phytopathology, v.83, n.8, p.834-842, 1993 b.

LEE, I-M.; GUNDERSEN-RINDAL, D. E.; DAVIS, R. E.; BARTOSZYK, I. M. Revised classification scheme of phytoplasmas based on RFLP analyses of 16SrRNA and ribosomal protein gene sequences. International Journal of Systematic Bacteriology, v.48, p.1153-1169, 1998. 
LOPES, M.T.V.C.; CAMARGO, L.E.A.; FOLEGATTI, M.E.; LOPES, J.R.S. Freqüência de molicutes associados ao enfezamento do milho em algumas localidades do estado de São Paulo. Fitopatologia Brasileira, v.22, p. 347, ago. 1997. Suplemento. /Apresentado ao 30. Congresso Brasileiro de Fitopatologia, Poços de Caldas, 1997 - Resumo/

MARAMOROSCH, K. The occurrence of two distinct types of corn stunt in Mexico. Plant Disease Reporter, v.39, n.12, p.896-898, 1955.

MARAMOROSCH, K. Non-chemical control of plant mycoplasma diseases. In: MARAMOSCH, K.; RAYCHAUDHURI, S.P. Mycoplasma diseases of crops - basic and applied aspects. New York: Springer-Verlag, 1988. cap. 23, p.431-449.

MASSOLA JÚNIOR, N.S. Avaliação de danos causados pelo enfezamento vermelho e enfezamento pálido na cultura do milho. Piracicaba, 1998. 75p. Tese (Doutorado) - Escola Superior de Agricultura "Luiz de Qu Universidade de São Paulo.

MASSOLA JÚNIOR, N.S.; BEDENDO,I.P.; AMORIM;L.; LOPES, J.R.S. Danos provocados pelo complexo do enfezamento na cultura do milho. In: SEMINÁRIO SOBRE A CULTURA DO MILHO "SAFRINHA", 4., Assis, 1997. Anais. Assis: IAC,CDV, 1997. p.95-99.

MASSOLA, N.S.; BEDENDO, I.P.; AMORIM, L.; LOPES, J.R.S. Quantificação de danos causados pelo enfezamento vermelho e enfezamento pálido do milho em condições de campo. Fitopatologia Brasileira, v.24, p.136-142, 1999. 
McCOY, R.E.; LEEUW, G.T.N.; MARTWITZ, R.; CHEN, M.T Plant diseases associated whit mycoplasma-like organisms. In: WHITCOMB, R.F; TULLY, J.G. The mycoplasmas V: Spiroplasmas, acholeplasmas, and mycoplasmas of plants and arthropods. San Diego: Academic Press, 1989, p 602.

NAULT, L.R. Maize bushy stunt and corn stunt: a comparison of disease symptoms, pathogen host ranges, and vectors. Phytopathology, v.70, p.659$662,1980$.

OLIVEIRA, E.; WAQUIL, J.M.; PINTO, N.F.J.A. Doenças causadas por patógenos transmitidos por insetos: complexo do enfezamento/mosaico. In: SEMINÁRIO SOBRE A CULTURA DO MILHO "SAFRINHA”, 4., Assis, 1997. Anais. Assis: IAC,CDV, 1997. p.87-94.

OLIVEIRA, E.; WAQUIL, J.M.; FERNANDES, F.T.; PAIVA, E.; RESENDE, R.O.; KITAJIMA, E.W. Enfezamento pálido e enfe zamento vermelho na cultura do milho no Brasil Central. Fitopatologia Brasileira, v.23, p.45-47, 1998.

RAHMAN, K.V. Maize diseases - Brazil: www.agnic.org/pmp/1996/mdl9607.html. (30 ago. 1998).

SEARS, B.B.; KIRKPATRICK, B.C. Unveiling the evolutionary relationships of plant pathogenic mycoplasma-like organisms. ASM News, v.60, p.307$312,1994$.

SEEMULLER, E.; MARCONE, C.; LAUER, U.; RAGOZZINO, A.; GÖSCHL, M. Current status of molecular classification of the phytoplasmas. Journal of Plant Pathology, v. 80, n.1, p.3-26, 1998,

SHURTLEFF, M.C. Compendium of Corn Diseases. 2 ed. St Paul: American Phytopathological Society, 1986. 105p. 
SINCLAIR, W.A.; GRIFFITHIS, H.M; DAVIS, R.E. Ash yellows and llac witches'-broom: phytoplasmal diseases of concern in forestry and horticulture. Plant Disease, v.80, n.5, p.468-475, May 1996.

SCOTT, G.E.; ROSENKRANZ, E.E.; NELSON, L.R. Yield loss of corn due to corn stunt disease complex. Agronomy Journal, v.69, p.92-94, Jan./Fev., 1977.

TOFFANELLI, C.M. Efeito do fitoplasma do enfezamento vermelho e da população de vetores infectivos sobre os sintomas e componentes de produção. Piracicaba, 2001. 68p. Dissertação (Mestrado) Escola Superior de Agricultura “Luiz de Queiroz”, Universidade de São Paulo.

TOFFANELLI, C.M., BEDENDO, I.P. Efeito da inoculação do fitoplasma do enfezamento sobre o desenvolvimento e produção de híbridos de milho. Fitopatologia Brasileira,. 2001. /No prelo/.

TSAI, J. H.; FALK, B.W. Insect vectors and their pathogens of maize in the tropics. http:// ipmworld.umn.edu/chapters/tsai.htm. (30 ago. 1998).

ULLSTRUP, A.J. Corn diseases in the United States and their control. Washington: USDA, 1978. 55p. (USDA. Agriculture Handbook, 199).

WHITCOMB, R.F. Spiroplasma kunkelli: biology and ecology. In: WHITCOMB, R.F; TULLY, J.G. The mycoplasmas V: spiroplasmas, acholeplasmas, and mycoplasmas of plants and arthropods. San Diego: Academic Press, 1989. cap.10, p.488-533. 